\title{
Economy wide risk diversification in a three-pillar pension system
}

Citation for published version (APA):

Du, C., Muysken, J., \& Sleijpen, O. C. H. M. (2010). Economy wide risk diversification in a three-pillar pension system. METEOR, Maastricht University School of Business and Economics. METEOR Research Memorandum No. 055 https://doi.org/10.26481/umamet.2010055

Document status and date:

Published: 01/01/2010

DOI:

10.26481/umamet.2010055

Document Version:

Publisher's PDF, also known as Version of record

\section{Please check the document version of this publication:}

- A submitted manuscript is the version of the article upon submission and before peer-review. There can be important differences between the submitted version and the official published version of record.

People interested in the research are advised to contact the author for the final version of the publication, or visit the DOI to the publisher's website.

- The final author version and the galley proof are versions of the publication after peer review.

- The final published version features the final layout of the paper including the volume, issue and page numbers.

Link to publication

\footnotetext{
General rights rights.

- You may freely distribute the URL identifying the publication in the public portal. please follow below link for the End User Agreement:

www.umlib.nl/taverne-license

Take down policy

If you believe that this document breaches copyright please contact us at:

repository@maastrichtuniversity.nl

providing details and we will investigate your claim.
}

Copyright and moral rights for the publications made accessible in the public portal are retained by the authors and/or other copyright owners and it is a condition of accessing publications that users recognise and abide by the legal requirements associated with these

- Users may download and print one copy of any publication from the public portal for the purpose of private study or research.

- You may not further distribute the material or use it for any profit-making activity or commercial gain

If the publication is distributed under the terms of Article $25 \mathrm{fa}$ of the Dutch Copyright Act, indicated by the "Taverne" license above, 


\section{Maastricht University}

Cai Cai Du

Economy wide risk diversification in a three-pillar pension system

$\mathrm{RM} / 10 / 055$

\section{METEOR}

Maastricht University School of Business and Economics

Maastricht Research School of Economics

of Technology and Organization

P.O. Box 616

NL - 6200 MD Maastricht

The Netherlands 


\title{
Economy wide risk diversification in a three-pillar pension system
}

\author{
Cai Cai $\mathrm{Du}^{1}$ \\ Joan Muysken \\ Olaf Sleijpen \\ Department of Economics, SBE \\ Maastricht University \\ The Netherlands
}

29 October 2010

\begin{abstract}
We model a three-pillar pension system and analyse the impact of exogenous shocks on an open economy, using an overlapping generation model where individuals live for two periods. The three-pillar pension system consists of (1) a PAYG pension system, (2) a defined benefits pension fund, and (3) private savings. The economy is exposed to an ageing trend, inflation and a stock market crash. We show that in the three-pillar pension system the impact of these shocks on the economy is mitigated when compared to a twopillar system, since each shock has a different impact on the three pillars. In order to illustrate the working of the model with respect to the impact of shocks, both in magnitude and the development over time, we provide simulation results for the Netherlands.
\end{abstract}

${ }^{1}$ Corresponding author: Tel: 0031 643029504; Email address: C.Du@ maastrichtuniversity.nl 


\section{Introduction}

In order to elaborate the distinct functions that pensions have in a macro- and microeconomic context, the World Bank (1994) has introduced a three-pillar system to classify existing pension systems. In a macroeconomic context it is widely recognised that first pillar state pensions, financed on a pay-as-you-go basis, help in providing basic old-age benefits and are not very vulnerable to inflation. However, the second and third pillars, financed by collective and individual savings, respectively, supposedly provide a better solution in an ageing society, but are susceptible to inflationary and asset price developments.

In this paper we analyse how the three pillars relate to different exogenous (economic) shocks. Indeed, the current financial crisis has affected second and third pillar pensions markedly, triggering a discussion on the viability of the three pillars under different economic circumstances. Some have argued that the design of the pillars should be changed as to allow one pillar to act as a stabilising element when other pillars are affected by shocks, as these shocks have a distinct bearing on the pillars concerned (De Kam, et al., 2007).

Literature is rather abundant with respect to the analysis of shocks in a two-pillar pension system defined by a two-pillar with PAYG pensions and private savings. Most analyses use an OLG model in a closed economy context, although Henin and Weitzenblum (2005) assess the macroeconomic and welfare effects of pension reforms in an open economy. For instance, Değer (2008) investigates the effect of a replacement ratio shock, Fanti and Gori (2008) study the effects of increasing longevity and Heer and Irmen (2009) elaborate the effects of a declining labor force on economic growth, pensions and welfare for the US in an economy where the production technology is endogenous. Rahman (2008) analyses implications of demographic uncertainty under a two-pillar system with PAYG pensions and personal savings and a two-pillar system consisting of fully-funded pensions and personal savings in the context of a closed economy. Groezen, Meijdam and Verbon (2007) investigate the impact of reducing benefits of a PAYG-scheme and ageing 
in a two-sector (commodity and service) economy. Kemmerling and Neugart (2009) analyse the influence of financial market lobbies on pension policies.

In this paper, on the contrary, we analyse the impacts of shocks under a three-pillar pension system. The aim of our paper is to demonstrate the advantage of risk diversification under a three-pillar pension system in response to exogenous shocks, when compared to a one-pillar or two-pillar pension system. Our focus is quite different compared to previous literature on three-pillar systems.

Draper, Knaap and Westerhout (2003) develop the GAMMA model with a three-pillar pension system which reflects the situation of the Netherlands quite well but it is too complex to derive tractable solutions. Their aim is to evaluate the effects of four shocks (a decrease in interest rate, a decline in wage growth, a stock market crash and an increase in life expectancy) on the welfare of different generations under different types of funded pension systems. Draper and Armstrong (2007) use the GAMMA model for projections and simulations of the outcomes of demographic shocks, tax system reform and pension system reform under a three-pillar pension system in an open economy. In a similar vein Benkovskis (2006) models the effect of increasing the fully funded pillar's share and the retirement age on Latvian total saving and their components in a small open economy. Verbic (2007) analyses the welfare effects and macroeconomic effects of an increase in the age of retirement and a lower level of ambition with respect to the indexation of pensions to wages using the SIOLG 2.0 model (a dynamic overlappinggenerations general equilibrium model of the Slovenian economy).

Bovenberg and Uhlig (2006) use an OLG model to derive the social planner's solution to optimal intergenerational risk sharing and redistribution between old, young and future generations. In the decentralised economy they do not present an analytical solution of consumption and savings, but explore how to use lump-sum transfers to realise the social planner's solution. Bonenkamp and Westerhout (2010) adopt a relatively simple OLG model to derive analytically that the welfare gains from intergenerational risk sharing dominate the welfare losses from the labor market distortions in the collective funded pension schemes. As their focus is on the advantage of the collective funded pension schemes, they do not consider the public PAYG pension scheme in their model. Broer 
(2010) mentions that the PAYG pension scheme and funded pension scheme expose individuals to different kind of risks. But his paper focuses on the distributions of these risks and how the pension returns are associated with the risks.

The paper is organised as follows. In Section 2 our model of an open economy, consisting of two overlapping generations with a three-pillar pension system, is presented. Section 3 presents the steady state solution of the model and analyses the impact of different exogenous shocks. In particular, the impact of a shock in returns on financial assets (bonds and equity) is considered, as well as a change in the participation rate, the actual inflation rate, population growth, the survival rate and the impact of the division of the contribution to the pension fund between the firms and the workers. Section 4 presents a calibration of the model, based on data for The Netherlands. Moreover, the impact of three shocks is simulated, i.e. a demographic shock, an inflation shock as well as a drop in equity return comparable to the 2008 financial crisis. Section 5 concludes.

\section{The model}

The model consists of firms, consumers in two overlapping generations, a public sector and a pension fund. Firms operate under full competition and maximise profits. The inputs are labour and capital. The return on capital is exogenously given, assuming a small open economy. The wage costs are the sum of the wage received by the workers and the pension premium paid by the firm.

Consumers live two periods. In the first period, individuals supply labour and earn a wage income at an exogenous participation rate. In the second period, only part of the individuals survive. The survivors are retired and receive pensions from the public sector (first pillar) and the pension fund (second pillar). Consumers aim to maximise their lifetime utility by choosing savings in the first period (third pillar). They invest their savings in bonds only. 
The public sector taxes the workers in order to pay public pensions proportional to the current wage rate to all retired individuals. The public pension scheme is of the PAYG type.

The pension fund receives contributions from the firms and the workers, and pays pensions proportional to the previous wage rate to the retired workers. The pension fund invests in equities and the workers are obliged to participate in the fund. Since the pension benefits are not directly related to asset market rates of return, shocks to the pension wealth are absorbed by the contribution rate (except under extreme situations).

\section{$2.1 \quad$ Firms}

Firms use labour $L_{t}$ and capital $K_{t}$ to produce output $Y_{t}$, according to a Cobb-Douglas production function:

$Y_{t}=A_{t} K_{t}^{\alpha} L_{t}^{1-\alpha}$

Here $A_{t}$ measures the productivity level, which grows at a rate $g$.

Firm behaviour is based on profit maximisation. This yields:

$$
\begin{aligned}
& w_{t}^{c}=w_{t}\left(1+\beta \tau_{t}^{p}\right)=(1-\alpha) A_{t} K_{t}^{\alpha} L_{t}^{-\alpha} \\
& r_{t}^{k}=\alpha A_{t} K_{t}^{\alpha-1} L_{t}^{1-\alpha}
\end{aligned}
$$

Real wage cost $w_{t}^{c}$ consist of the real wage $w_{t}$, received by the workers, and the share $\beta$ $(0 \leq \beta \leq 1)$ of the real pension premium $\tau_{t}^{p}$, which is paid by the employer. We assume a small open economy, which implies that the real rate of capital return is determined on the world market - hence $r_{t}^{k}$ is given. Finally employment $L_{t}$ is equal to the exogenous participation of the young individuals, $p N_{t}$ - we elaborate the latter below. 
Equations (2) and (3) can be combined to yield an expression of the capital stock and the wage rate in terms of exogenous variables:

$$
\begin{aligned}
& K_{t}=\left(A_{t} \frac{\alpha}{r_{t}^{k}}\right)^{\frac{1}{1-\alpha}} p N_{t} \\
& w_{t}=(1-\alpha) A_{t}^{\frac{1}{1-\alpha}}\left(\frac{\alpha}{r_{t}^{k}}\right)^{\frac{\alpha}{1-\alpha}} \frac{1}{1+\beta \tau_{t}^{p}}
\end{aligned}
$$

\subsection{Consumers}

We assume an overlapping generation model with two generations: young and old. There are $N_{t}$ young individuals, who participate in the labour market at a rate $p(0<p \leq 1)$. The growth rate of $N_{t}$ is $n$. All participating young individuals earn a real wage income $w_{t}$, from which they contribute to the public sector benefits and the pension fund at rates $\tau_{t}^{g}$ and $(1-\beta) \tau_{t}^{p}$, respectively. Net income then is spent on consumption and savings. The savings are invested in bonds.

Only a fraction $\varepsilon$ of young individuals survives to the next period. During that period the individuals are old and at the end of that period they die. An increase in the fraction $\varepsilon$ then can be used to mimic the process of ageing. When old, the individuals do not work, but receive a public pension $\eta_{t}^{g}$ and a pension $\eta_{t}^{p}$ from the pension fund 2 Moreover, they use the returns on their savings, as well as the savings themselves, to finance consumption in retirement. The individuals therefore face the following real budget constraints in their two periods of life:

$$
\begin{aligned}
& c_{t}^{y}=\left[1-\tau_{t}^{g}-(1-\beta) \tau_{t}^{p}\right] p_{t} w_{t}-s_{t} \\
& c_{t+1}^{o}=\frac{1+\lambda_{t+1}}{\varepsilon} s_{t}+\eta_{t+1}^{g}+\eta_{t+1}^{p}
\end{aligned}
$$

\footnotetext{
${ }^{2}$ Actually, only those who have worked when young receive a pension, but in our aggregate analysis we take that into account by including the participation rate in equation (8) below.
} 
Here $c_{t}^{y}\left(c_{t+1}^{o}\right)$ is the consumption of the young (old) and $s_{t}$ is savings. The bonds earn an expected real return $\lambda_{t}$, with $1+\lambda_{t}=\frac{\left(1+r_{t}^{b}\right)\left(1+\pi_{t}^{e}\right)}{\left(1+\pi_{t}\right)}$. Here $r_{t}^{b}$ is the real return on bonds, $\pi_{t}^{e}$ is the expected inflation rate and $\pi_{t}$ is the actual inflation rate. Because only a fraction $\varepsilon$ of individuals survives to the next period, the assets of those who deceased fall to surviving contemporaries. The total real return on savings then is $\frac{1+\lambda_{t}}{\varepsilon}-1$.

The pension from the pension fund is a fraction $\xi^{p}$ of the past wage. It should also be corrected for the participation rate in the young period, to allow for consumption by all old consumers (including those who did not fully participate when young). Moreover, the pension fund fully compensates the effect of inflation on the pension. Thus we find:

$\eta_{t+1}^{p}=\xi^{p} p w_{t}$

The public pension is a fraction $\xi^{g}$ of the current wage (in order to relate it to the wage in the previous period we use the fact that the real wage grows with productivity growth $g$ ), hence:

$\eta_{t+1}^{g}=\xi^{g} w_{t+1}=\xi^{g} w_{t}(1+g)$

Given the budget constraints (6) and (7), the individuals maximise their expected lifetime utility represented by

$E U_{t}=\frac{\left(c_{t}^{y}\right)^{1-\theta}}{1-\theta}+\gamma \varepsilon \frac{\left(c_{t+1}^{o}\right)^{1-\theta}}{1-\theta}$

where $\gamma$ measures the rate of time preference of the individual and $1 / \theta>0$ is the elasticity of intertemporal substitution. Maximising equation (10) subject to the budget constraints results in the following first-order condition 


$$
\frac{c_{t+1}^{o}}{c_{t}^{y}}=\left[\gamma\left(1+\lambda_{t+1}\right)\right]^{\frac{1}{\theta}}
$$

Combing equations (6) and (7) with equation (11) gives the following individual consumption and saving functions:

$$
\begin{aligned}
& c_{t}^{y}=\Lambda_{t} w_{t} \\
& c_{t+1}^{o}=\left(\gamma\left(1+\lambda_{t+1}\right)\right)^{\frac{1}{\theta}} \Lambda_{t} w_{t} \\
& s_{t}=\left\{\left[1-\tau_{t}^{g}-(1-\beta) \tau_{t}^{p}\right] p-\Lambda_{t}\right\} w_{t}
\end{aligned}
$$

Where $\Lambda_{t}=\frac{\left(1+\lambda_{t+1}\right)\left[1-\tau_{t}^{g}-(1-\beta) \tau_{t}^{p}\right] p+\varepsilon\left[\xi^{p} p+\xi^{g}(1+g)\right]}{1}$ and the wage rate is given

$$
\varepsilon\left(\gamma\left(1+\lambda_{t+1}\right)\right)^{\bar{\theta}}+\left(1+\lambda_{t+1}\right)
$$

by equation (5).

\subsection{The public sector}

The public sector receives taxes from the workers for paying the pension benefits $\eta_{t+1}^{g}$ to the retirees according to equation (9). The pension scheme is of a pay-as-you-go nature. Hence, the real budget constraint of the public sector is given by:

$$
\varepsilon \eta_{t+1}^{g}=\tau_{t+1}^{g}(1+n) p w_{t+1}
$$

Substituting equation (9) then yields:

$$
\tau_{t+1}^{g}=\frac{\varepsilon \xi^{g}}{(1+n) p}
$$

This shows that the premium decreases with population growth and the participation rate, whereas it increases with ageing and a higher benefit. 


\subsection{The pension fund}

The pension fund has real financial wealth $W_{t}^{p}$ at the start of a period, it receives premium income $\tau_{t}^{p} p w_{t}$ from firms and workers and pays pension benefits $\eta_{t}^{p}$ to retirees according to equation (8). The fund invests all its assets in equity which yield an expected real return $\mu_{t}$, with $1+\mu_{t}=\frac{\left(1+r_{t}^{e}\right)\left(1+\pi_{t}^{e}\right)}{1+\pi_{t}}$. The real return on equity $r_{t}^{e}$ includes anticipated price changes of equity, corrected for inflation.

Thus the pension fund real wealth accumulates according to:

$W_{t+1}^{p}=\left(1+\mu_{t+1}\right)\left(W_{t}^{p}+\tau_{t}^{p} N_{t} p w_{t}-\varepsilon N_{t-1} \eta_{t}^{p}\right)$

The pension fund wants to make the wealth equal to the liability - the latter equals $\varepsilon N_{t-1} \eta_{t}^{p}$ in the steady state. The pension fund will adjust its premium when the thus accumulated wealth does not meet its target value, such that the wealth accumulation is back to its target value in $1 / \varphi$ years. Hence:

$W_{t+1}^{p}=\varepsilon N_{t} \eta_{t+1}^{p}-\varphi\left(W_{t}^{p}-\varepsilon N_{t-1} \eta_{t}^{p}\right)$

In the steady state, where the pension fund meets its liabilities, we have

$W_{t}^{p}=\varepsilon N_{t-1} \eta_{t}^{p}$

Assuming that in that situation expected inflation also equals actual inflation we find for the pension fund premium $\tau_{t}^{p}$ from equations (8), (17) and (19):

$\tau_{t}^{p}=\frac{\varepsilon \xi^{p}}{1+r_{t}^{e}}$ 
Equation (20) shows that in the steady state the premium decreases with higher returns on equity and increases with ageing and a higher benefit.

In a situation where the pension fund does not meet its liabilities, we find combining equations (17) and (18):

$$
\tau_{t}^{p}=\frac{\varepsilon N_{t} \eta_{t+1}^{p}-\left(1+\mu_{t}+\varphi\right)\left(W_{t}^{p}-\varepsilon N_{t-1} \eta_{t}^{p}\right)}{\left(1+\mu_{t}\right) N_{t} p_{t} w_{t}}
$$

This converges to the steady state premium (20) when the pension fund meets its liabilities and expected inflation also equals actual inflation.

An interesting question arises when the equity return is risky, with an expected variance of $\sigma^{2}$. The expected value of the equity return $\mu_{t}$ is not affected, but because $\left(W_{t}^{p}-\varepsilon N_{t-1} \eta_{t}^{p}\right)$ depends on the actual equity return, $\tau_{t}^{p}$ is stochastic now. As a consequence one can derive from equation (21) that the variance of $\tau_{t}^{p}$ equals

$$
\begin{aligned}
& \operatorname{Var}\left(\tau_{t}^{p}\right)=\left[\frac{1+\mu+\varphi}{(1+\mu) N_{t} p_{t} w_{t}}\right]^{2} \operatorname{Var}\left(W_{t}^{p}\right)= \\
& {\left[\frac{1+\mu+\varphi}{(1+\mu) N_{t} p_{t} w_{t}}\right]^{2}\left(W_{t-1}^{p}+\tau_{t-1}^{p} N_{t-1} p_{t-1} w_{t-1}-\varepsilon N_{t-2} \eta_{t-1}^{p}\right)^{2} \sigma^{2}}
\end{aligned}
$$

It is obvious that the larger the variance of the equity return the higher the variance of $\tau_{t}^{p}$.

\subsection{The complete model}

The complete model is given by equations (5), (12) - (14), (16) and in the steady state equation (20). Assuming the steady state, we also have $\lambda_{t}=r_{t}^{b}$. When we assume all rates of return, as well as the participation rate, to be constant over time, the model can be 
solved in a straightforward way. We elaborate this in the steady state solution in Section 3. This also allows us to analyse the impact of shocks to economy in a comparative static context. To consider the properties of the model during the transition period in response to shocks we have to resort to simulations, since the dynamics of the model then become intractable analytically. The simulation results are presented in Section 4.

\section{The steady state}

In Section 3.1 we solve the model for the steady state. In the steady state, actual inflation equals expected inflation and the financial wealth of the pension fund is equal to its liabilities in every period. In Section 3.2 we investigate the comparative statics properties of the model by analysing the impact of exogenous shocks on the steady state solution.

\subsection{The steady state solution}

From the presentation of the model in the previous section it follows directly that the steady state is characterised by the following equations: ${ }^{3}$

$c^{y}=\Lambda w$

$$
\begin{aligned}
c^{o} & =\left[\gamma\left(1+r^{b}\right)\right]^{\frac{1}{\theta}} \Lambda w \\
s & =\left\{\left[1-\tau^{g}-(1-\beta) \tau^{p}\right] p-\Lambda\right\} w
\end{aligned}
$$

Where $\Lambda=\frac{\left(1+r^{b}\right)\left[1-\tau^{g}-(1-\beta) \tau^{p}\right] p+\varepsilon\left[\xi^{p} p+\xi^{g}(1+g)\right]}{\varepsilon\left[\gamma\left(1+r^{b}\right)\right]^{\frac{1}{\theta}}+\left(1+r^{b}\right)}$

$w=(1-\alpha) A^{\frac{1}{1-\alpha}}\left(\frac{\alpha}{r^{k}}\right)^{\frac{\alpha}{1-\alpha}} \frac{1}{1+\beta \tau^{p}}$

$\tau^{g}=\frac{\varepsilon \xi^{g}}{(1+n) p}$

$$
\tau^{p}=\frac{\varepsilon \xi^{p}}{1+r^{e}}
$$

\footnotetext{
${ }^{3}$ We omit the time subscript of each variable, since it is not relevant in the steady-state.
} 
The variables on the left-hand side of equations (23) - (28) are the endogenous variables and the other variables $r^{b}, r^{e}, r^{k}$ and $p$ are exogenous.

From equations (27) and (28) one sees that the "return" on the PAYG premium is given by $(29 a),{ }^{4}$ while in a normal situation the "return" on the pension premium is given by equation (29b). Finally we know from the discussion on consumer behaviour that the return on savings is given by $(29 \mathrm{c})$ :

$$
\begin{aligned}
& \frac{\xi^{g} w(1+g)}{\tau^{g} w}-1=\frac{(1+n)(1+g) p}{\varepsilon}-1 \\
& \frac{\xi^{p}}{\tau^{p}}-1=\frac{1+r^{e}}{\varepsilon}-1 \\
& \frac{1+r^{b}}{\varepsilon}-1
\end{aligned}
$$

The return on pension funds therefore is larger than that on public pensions as long as $1+r^{e}>(1+n)(1+g) p$, and it exceeds that on private savings as long as $r^{e}>r^{b}$. By having a pension system which consists of three pillars, the pension is essentially spread over a portfolio with different rates of return, as equation (29) illustrates. One hedges against inflation and asset price risk by using a PAYG system, one hedges against demographic risk by using a pension fund, and one allows for individual risk preferences by using private savings next to a pension fund 5 Therefore the three-pillar system mitigates the impact of different types of shocks. We elaborate that point in the next section where we present simulation results. But first we analyse the impact of different types of shocks in the steady state.

3.2 The impact of exogenous shocks on the steady state

\footnotetext{
${ }^{4}$ Individuals pay $\tau^{g} w$ in the young period and receive $\xi^{g} w(1+g)$ in the old period. Therefore, the return on the PAYG premium is given by equation (29a)

${ }^{5}$ One might argue that actually the pension fund should be the safe investor, and private pensions then should allow for more risk-taking behaviour (Muysken, 2010), but that does not represent the current situation.
} 
The impact of shocks to pension benefits, returns of bonds and equity, the inflation rate, the participation rate, the survival rate and population growth on the endogenous variables of the model is summarised in Table $1{ }^{6}$ In order to compare our findings to the results from other literature we discuss here the impact of a change in benefits for both types of pensions. We elaborate on some more findings when we discuss the simulation results presented in the next section.

The results of Table 1 indicate that in our model a decrease of the public pension benefits leads to a lower PAYG-tax rate, while the pension premium does not change. The decrease of the benefits increases savings, which illustrates the substitutability of savings for pensions. The response of consumption of both generations depends on whether $\left(1+r^{b}\right)>(1+g)(1+n)$, or not. The reason is that the lifetime income, out of which both consumptions are financed, increases when the return on savings $\left(1+r^{b}\right)$ is higher than the return on the public pension contribution $(1+g)(1+n)$ - compare equations (29a) and $(290) \cdot{ }^{7}$ In that case a decrease of the public pension leads to an increase of consumption of both generations.

\footnotetext{
${ }^{6}$ In the appendix section 1 the derivations and resulting conditions underlying Table 1 are presented.

${ }^{7}$ Because the participation rate is $p$, the return on the public pension contribution should be divided by $p$.
} 
Table 1 The impact of exogenous shocks on the economy

\begin{tabular}{|c|c|c|c|c|c|c|}
\hline & & \multicolumn{2}{|c|}{ Premiums } & \multicolumn{2}{|c|}{ Consumption } & \multirow[t]{2}{*}{ Savings } \\
\hline & & PAYG & Pension & Young & Old & \\
\hline & & $\tau^{g}$ & $\tau^{p}$ & $c^{y}$ & $c^{o}$ & $s$ \\
\hline PAYG benefits & $\xi^{g}$ & + & 0 & $-*$ & $-*$ & - \\
\hline Pension benefits & $\xi^{p}$ & 0 & + & $-* *$ & $-* *$ & - \\
\hline Employer contrib. & $\beta$ & 0 & 0 & $?$ & ? & ? \\
\hline \multirow[t]{2}{*}{ Inflation } & $\pi=\pi^{e}$ & 0 & 0 & 0 & 0 & 0 \\
\hline & $\pi \neq \pi^{e}$ & 0 & + & $?$ & - & - \\
\hline Bonds returns & $r^{b}$ & 0 & 0 & $-* * *$ & $+* * *$ & $+* * *$ \\
\hline Equity returns & $r^{e}$ & 0 & - & + & + & + \\
\hline Participation rate & $p$ & - & 0 & + & + & + \\
\hline Population growth & $n$ & - & 0 & + & + & + \\
\hline Survival rate & $\varepsilon$ & + & + & - & - & - \\
\hline
\end{tabular}

\footnotetext{
* A sufficient condition is $\left(1+r^{b}\right)>(1+g)(1+n)$

** A sufficient condition is $\frac{1+r^{e}}{1-\beta}<\left(1+r^{b}\right)$

*** A sufficient condition is $\frac{1}{\theta}>1$
}

This outcome of our model is consistent with the conclusions of a study of national savings by Edwards(1996), who used a panel of 36 OECD, Latin American and East Asian countries (but excluding the USA and UK) and of Kemmerling and Neugart (2009), Henin and Weitzenblum (2005). Private savings were negatively related to the social security spending. On the other hand, Groezen, Meijdam and Verbon (2007) concluded that a decrease of the public pension decreases consumptions in both periods. However, they analysed a closed two-sector economy with factor prices determined by the capitallabor ratio. In that context a lower PAYG-tax rate caused by a decrease of the public pension implies a lower rate of return to savings and more expensive services when retired. Then individuals have a strong incentive to save more to smooth consumptions in 
both periods. As a result, they increase savings more than the rise of net wage, so that consumptions in both periods decrease eventually. Verbic (2007) found similar results as our results when simulating the SIOLG 2.0 model.

From Table 1 one also sees that in our model a decrease of the benefits from the pension fund causes a lower pension premium, while the PAYG-tax rate is not affected. Again the decrease of the benefits increases savings, which illustrates the substitutability of savings for pension benefits. This result is the same as in Draper and Armstrong (2007), in which they simulated the effect of a smaller pension scheme. Also in accordance with their findings, the response of the consumption of both generations is ambiguous. If $\frac{1+r^{e}}{1-\beta}<\left(1+r^{b}\right)$ the response of consumption of both generations is negative. The reason is that the lifetime income, out of which both consumptions are financed, decreases when the return on savings $\left(1+r^{b}\right)$ is higher than the return on the pension premium $\frac{1+r^{e}}{1-\beta}<\left(1+r^{b}\right)-$ compare equations $(29 b)$ and $(29 c) .8$ In this case a decrease of the pension fund pension leads to an increase of consumption of both generations.

\section{Simulations}

In this section we use simulations to analyse the dynamics of the model. We focus on three shocks -an ageing population, inflation and a stock market crash - which represent current economic (potential) problems. An interesting aspect of these shocks is that they demonstrate the relative strengths and weaknesses of both pension systems. As we already mentioned in the introduction, first pillar state pensions, financed on a pay-asyou-go basis, help in providing basic old-age benefits and are not very vulnerable to inflation -see also equation (29a). However, the second and third pillars, financed by collective and individual savings, respectively, supposedly provide a better solution in an

\footnotetext{
${ }^{8}$ Individuals only pay part of the pension premium so the return on the pension premium should be divided by $(1-\beta)$.
} 
ageing society, but are susceptible to financial developments - see also equations (29b) and $(29 \mathrm{c})$, respectively.

We discuss the simulation results below, but first we present the baseline simulation in Section 4.1, based on parameter values which reflect the current state of the Dutch economy. In Section 4.2 we then present the simulation results of an ageing population. The simulation of an increase in the inflation rate are analysed in Section 4.3. Finally we discuss the impact of a shock in the stock market in Section 4.4 and pay separate attention to the impact of increased equity risk in section 4.5 .

\subsection{The base-line simulation}

For simulation purposes we cannot use the model $(21)-(26)$, which we used in the previous section to derive the steady state results for two reasons. First, since we want to analyse the dynamics after a shock we cannot assume that the pension fund always meets its liabilities. Hence the pension premium will fluctuate to satisfy wealth adjustment of the pension fund according to equation (21). Second, the model we used above is a discrete two-period model which periods stressing over many years, say young persons live 40 years and old persons live 20 years. The dynamics after a shock require, however, that we use a continuous time model which allows us to simulate on a year-by-year basis. For that reason we have used in the simulations a continuous time version of the model developed in section 2 with a variable pension premium. This model is presented in the Appendix section 2 .

Most parameter values for the simulations are taken from the GAMMA model (CPB, 2007), which has been developed by the Central Planning Bureau to reflect the situation in the Netherlands. The output elasticity of capital stems from Groezen, Meijdam and Verbon (2007), while the initial productivity is chosen equal to unity for simplicity. The real rate of return to capital is taken as the average of the corresponding rates for bonds and equity. The ratio of the number of young to the number of old persons is around 2 for the Netherlands. The PAYG and the pension fund benefits, as well as the part of the 
pension premium paid by the firm, are chosen to reflect the Dutch situation. The resulting parameter values are presented in Table 2 .

Table 2 The parameters values used in the simulations

\begin{tabular}{|ll|}
\hline Intertemporal substitution elasticity $(1 / \theta)^{*}$ & 0.5 \\
Time preference $(\rho)^{* 9}$ & $1.3 \%$ \\
Ratio of old to young** & 0.5 \\
Population growth rate $(n)$ & 0 \\
Participation rate $(p)^{*}$ & $78 \%$ \\
Initial productivity $(A)$ & 1 \\
Real productivity growth rate $(g)^{*}$ & $1.7 \%$ \\
Output elasticity of capital $(\alpha)$ & 0.3 \\
Real return on bonds $\left(r^{b}\right)^{*}$ & $2 \%$ \\
Real return on equity $\left(r^{e}\right)^{*}$ & $3.5 \%$ \\
Real return on capital $\left(r^{k}\right)$ & $2.75 \%$ \\
Inflation rate $(\pi)^{*}$ & $2 \%$ \\
PAYG benefit $\left(\xi^{g}\right)^{* *}$ & $30 \%$ \\
Pension fund benefit $\left(\xi^{p}\right) * *$ & $50 \%$ \\
The part of the pension premium paid by the firm $(\beta)$ & 0.75 \\
\hline So & \\
\hline
\end{tabular}

Source CPB (2007)

**Source Bonenkamp et al.(2010)

\footnotetext{
${ }^{9}$ The rate of time preference of $1.3 \%$ implies that the discount factor $\gamma$ for different year equals $1 /(1+0.013)^{t-25}$ with $25 \leq t \leq 85$, since individuals enter the economy at the age of 25 and die at 85 .
} 
Using the values of the parameters from Table 2 we have calculated the steady state values of the variables of our continuous time model. The resulting values of the PAYG tax rate, the pension premium, the consumption of the young and the old and the savings are presented in Table 3, where all values are expressed as a proportion of the wage the workers receive. Mind that the pension premium is the total value paid by the worker and the firm. The workers only need to pay $1 / 4$ of the total pension premium. The resulting premiums of $15 \%$ for PAYG pensions and $12.68 \%$ for the pension funds are plausible (Bonenkamp et al., 2010). Both the consumption of young and the savings reflect the average of the young generation. The consumption of old reflects the average of the old generation.

Table 3 Steady-state values of the variables, relative to wage

\begin{tabular}{|l|l|l|l|l|}
\hline $\begin{array}{l}\tau^{g} \\
(\text { PAYG tax } \\
\text { rate) }\end{array}$ & $\begin{array}{l}\tau^{p} \\
\text { (pension } \\
\text { premium) }\end{array}$ & $\begin{array}{l}c^{y} \\
\text { (consumption of } \\
\text { young) }\end{array}$ & $\begin{array}{l}c^{o} \\
\text { (consumption of } \\
\text { old) }\end{array}$ & $\begin{array}{l}s \\
\text { (savings) }\end{array}$ \\
\hline 0.15 & 0.1268 & 0.7725 & 0.6961 & 0.0545 \\
\hline
\end{tabular}

\subsection{The ageing population}

A disadvantage of a PAYG system (first pillar), as compared to pension funded by collective and private savings (second and third pillars, respectively), is that the first pillar is more vulnerable to the ageing problem - see also equation (29a). Since this problem is hotly debated in many countries, we want to evaluate this point using our model.

In our model ageing leads to a higher PAYG-tax rate as more old persons require the public sector to pay benefits. The higher tax rate leads to a lower lifetime income and hence has a negative impact on consumption of both generations and on savings with 
sensible values of parameters. Martins et al. (2005) concluded that the evolving population structure could have a strong negative impact on household savings, partly depending on the generosity and coverage of social systems - see also Masson and Tryon (1990). Both findings support our conclusion.

In our simulation we increase the ratio of the old to the young persons from 0.5 to 0.6 over 5 years. Period 1 represents the initial steady state situation, whereas the ratio starts to increase in period 2. In Figures $1-4$ we present the reactions of the pension premiums, consumption of the young, consumption of the old and savings, respectively. All variables are expressed as a fraction of wage received when young. We compare the results of a simulation of a system with and without a pension fund (second pillar), to show the impact of a PAYG scheme versus a funded scheme. In the situation without a pension fund individuals do not pay a pension premium and receive the $80 \%$ of the wage they earned from the PAYG scheme when old.

From Figure 1 one sees that in the baseline scenario the tax rate increases in line with the ratio of old to young, as predicted by our model, while consumption of both generations falls as can be seen in Figures 2 and $33^{10}$ The absence of a pension fund, however, requires a much higher tax rate from the PAYG system. And savings improve gradually because of the lower consumption in the young period - see Figure 4. The reason is that the return on the pension premium is higher than the return on the PAYG tax rate, compare equations (29b) and (29a), respectively. As a consequence the responses of consumption and savings are also larger in the case without the pension fund.

\footnotetext{
${ }^{10}$ The steady state values of consumption of young and old and of savings are different under both schemes, because in the base-line scenario we have $\xi^{g}=0,03$ and $\xi^{p}=0,05$, whereas under the alternative scheme we have $\xi^{g}=0,08$. Therefore the levels of consumption and savings under both schemes are different too. We correct for that by normalising the steady state levels of the alternative scheme to the level of the base line scenario.
} 
Figure 1 The adjustment path of the PAYG-tax rate

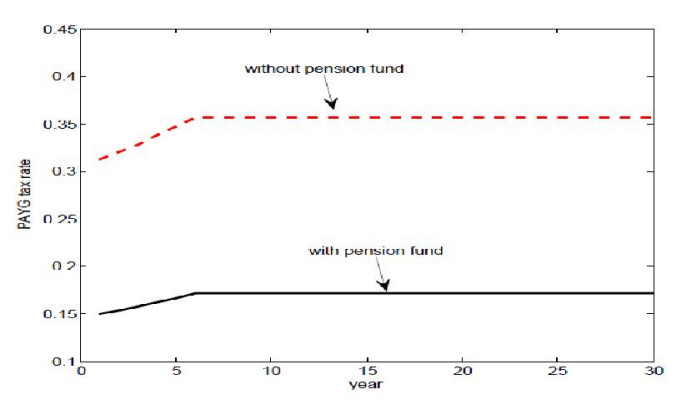

Figure 3 The adjustment path of consumption of old

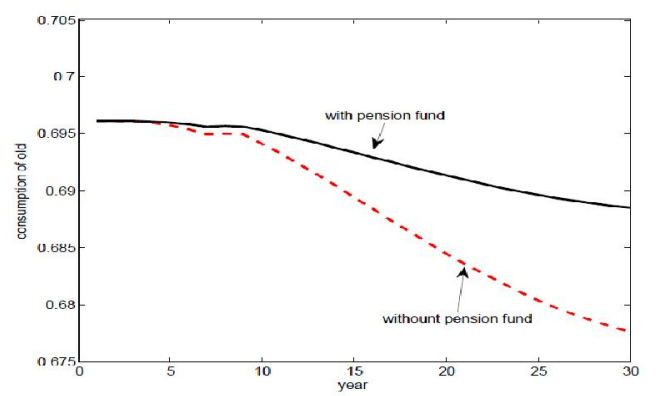

Figure 2 The adjustment path of consumption of young

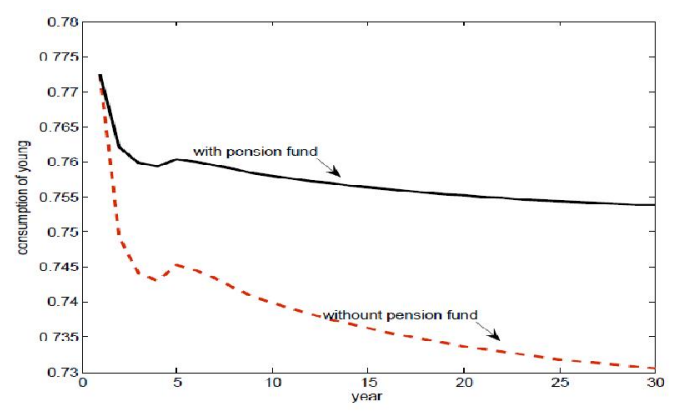

Figure 4 The adjustment path of savings

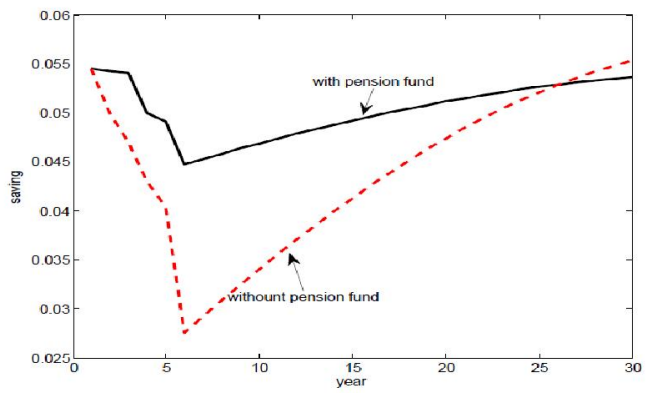

According to the figures, we can conclude that the consumption of the young decreases by $2 \%$ gradually and the consumption of the old decreases by $1 \%$ gradually. Bovenberg and Uhlig (2006) present similar results. They find a decrease in consumption of the young varying from $0.85 \%$ to $7.95 \%$ with different values of parameters when the longevity increases. Bonenkamp and Van de Ven (2006) find a decrease in the welfare of the young of $0.95 \%$ and a decrease in the welfare of the old varying from $0.03 \%$ to $2.6 \%$ depending on the types of the pension scheme. ${ }^{\text {T }}$

\footnotetext{
${ }^{11}$ Armstrong, Draper, Nibbelink and Westerhout (2007) suggest that private consumption increases from 45.8 billion of Euros to 55.1 billion of Euros when the old-age dependency ratio increases from $25 \%$ to $45 \%$, and similar results are found in Draper and Armstrong (2007). This increase in the private consumption is because of the higher proportion of retirees in population who consume more than they produce and because of fiscal arrangements such as the PAYG tax rate. Because of the strong growth of public pension government debt of the increases from $56.1 \%$ GDP to $211 \%$ GDP. In our analysis the negative effect of the ageing is born by the individuals to prevent increasing government debt. As a consequence consumption decreases.
} 


\subsection{An increase in the inflation rate}

A frequently mentioned advantage of a PAYG system, is that pensions funded by collective and private savings are much more sensitive to inflation. This can be seen from equation (29), where a shock in expected inflation will influence the returns on bonds and equity - see equations (29b) and (29c), respectively. We want to evaluate this point using our model, in particular since inflation might be a serious threat in the aftermath of the financial crisis. For that reason we model an unexpected increase in inflation to $4 \%$, from its initial level of $2 \%$, while expected inflation gradually adjusts to $4 \%$ in 3 periods.

Figure 5 The adjustment path of the pension premium

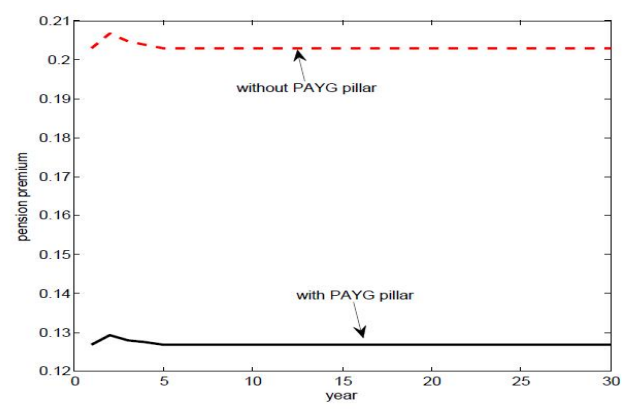

Figure 7 The adjustment path of consumption of old

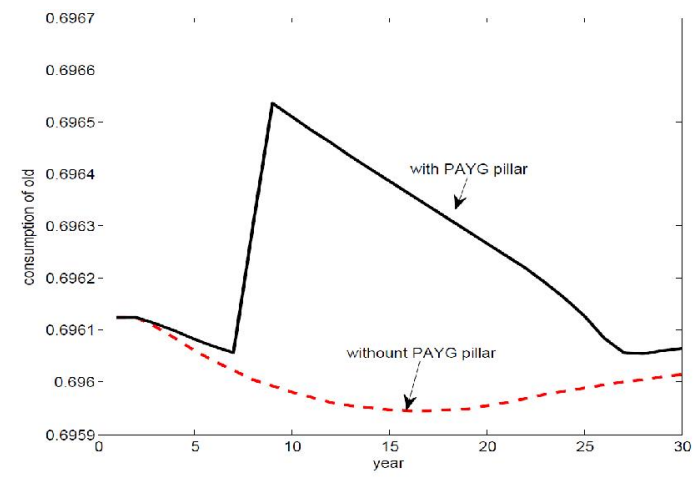

Figure 6 The adjustment path of consumption of young

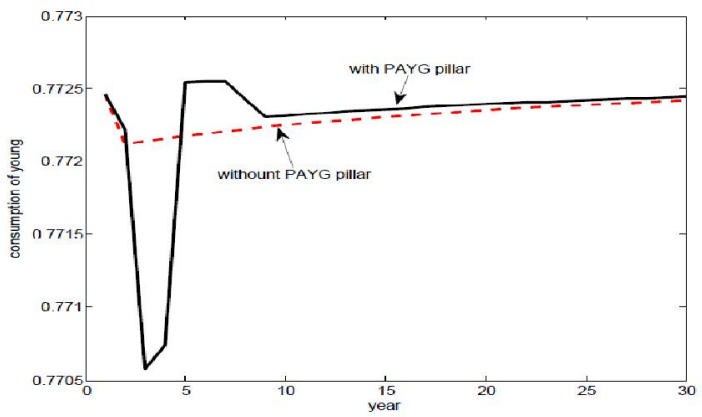

Figure 8 The adjustment path of saving

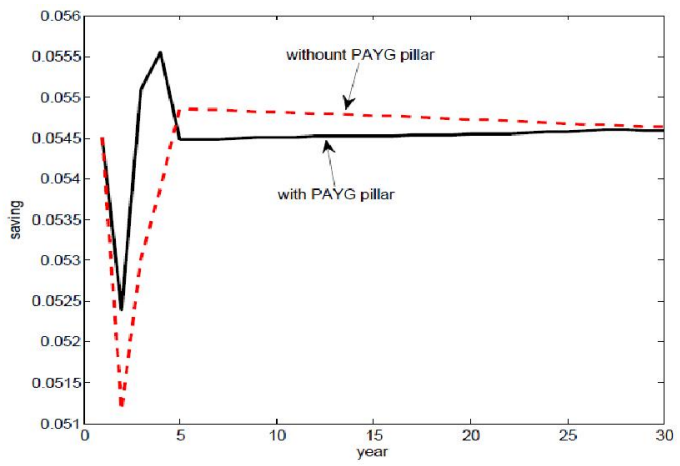

As we indicate in Table 1, anticipated changes in the inflation rate do not affect the pension premium, the PAYG-tax rate, consumption of both generations and savings in the steady state in our model. The reason is that the nominal returns on bonds and equity 
compensate the effect of inflation as long as expected inflation equals actual inflation. However, if expected inflation is unequal to actual inflation after a shock, the actual inflation rate will affect almost all variables in the model. The PAYG-tax rate does not respond to inflation because the public sector collects the taxes to pay for the public pensions in the same period - see also equation (29a). However, the inflation rate affects the pension premium positively since the real return on equity will fall - see equation (29b).

In our simulations we consider both the base-line situation with a PAYG pillar, and a situation without a PAYG pillar, to show the impact of a PAYG scheme versus a funded scheme. In the situation without PAYG benefits individuals do not pay the PAYG-tax rate and receive the $80 \%$ of the wage they earned from the pension fund when old. In Figures 5, 6, 7 and 8 we present the reactions of the pension premiums, consumption of the young, consumption of the old and savings, respectively. All variables are expressed as a fraction of wage received when young. Period 1 represents the initial steady state situation. Inflation increases to $4 \%$ in period 2 and remains at that level, while expected inflation catches up gradually and reaches $4 \%$ from period 5 onwards.

From Figure 5 one sees that the inflation shock indeed has a positive impact on the pension premium. Moreover, the impact is stronger in the absence of a PAYG pillar, since the PAYG premium is not affected by inflation. From Figures 6 and 7 one sees that in the steady state the negative response of consumption generations to the increase in inflation lasts longer in the situation without a PAYG pillar, reflecting the absence of inflation risk of that pillar.

It can be seen in Figure 6 that in the baseline simulation the consumption of young almost returns to the original level after 5 years, while the consumption of young in the situation without PAYG pillar gradually adjusts during 30 years. From Figure 7 one sees that the effect on consumption of old is larger and lasts longer when the PAYG pillar is absent. In that case the consumption of old decreases first because the members of the young generation whose savings decrease most enter the old generation. Then when the young members whose savings decrease less join the old, the consumption of old gradually 
returns. The base-line scenario can be explained by the same logic. There is an increase in the consumption of old after the shock because the young members who have more savings then enter the old generation - Figure 8 shows that in periods 4 and 5 savings are higher than the initial level after the initial negative shock. To sum up, the simulation results clearly show that consumption of both generations returns to its original level more quickly in the situation with a PAYG scheme than in the situation without. This illustrates that a PAYG scheme can have a stabilising effect in case of an inflationary shock.

\subsection{A fall in the stock market}

A frequently mentioned advantage of a PAYG system, as compared to a pension funded by collective savings, is that the latter are much more susceptible to stock market fluctuations - compare also equations (29a) and (29b). This is in particular relevant in the current situation of a financial crisis, where we witnessed strong fluctuations in the stock market. We use our model to evaluate the impact of these fluctuations, and consider the impact of a stock market crash, as we witnessed in 2008 in the Netherlands. In response to this unexpected shock, the pension fund will increase the pension premium.

We have simulated a shock in the stock market in period 2 which makes the pension fund wealth fall by $15 \%$, while the real return on equity permanently drops to $80 \%$ of its steady state value. Figures $9-12$ present the impact on the pension premium, consumption of young, consumption of old and savings, expressed as a fraction of wage received when young. We compare the results of a simulation of a system with and without a PAYG pillar, to show the impact of a PAYG scheme versus a funded scheme. In the situation without PAYG benefits, the old receive $80 \%$ of the wage they earned from the pension fund.

Figure 9 shows that in the baseline scenario the pension premium increases strongly as a result of the shock, which seems plausible given the drop in pension wealth. This factor contributes to a fall in consumption of young as can be seen from Figure 10. Although the pension benefits are not affected by the stock market crash, the decrease in the 
consumption of the old follows from the lower savings - compare Figures 11 and 12. The sharp decrease in savings observed in Figure 12 follows from the decline in life-time income due to the stock market crash, while the young want to maintain a certain level of consumption.

Figure 9 The adjustment path of Figure 10 The adjustment path of the pension premium consumption of young
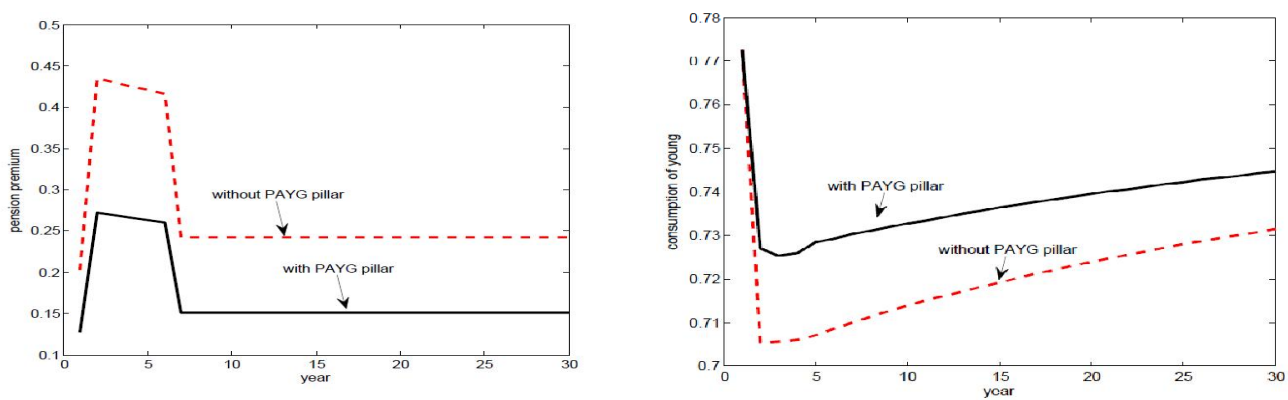

Figure 11 The adjustment path of consumption of old

Figure 12 The adjustment path of savings
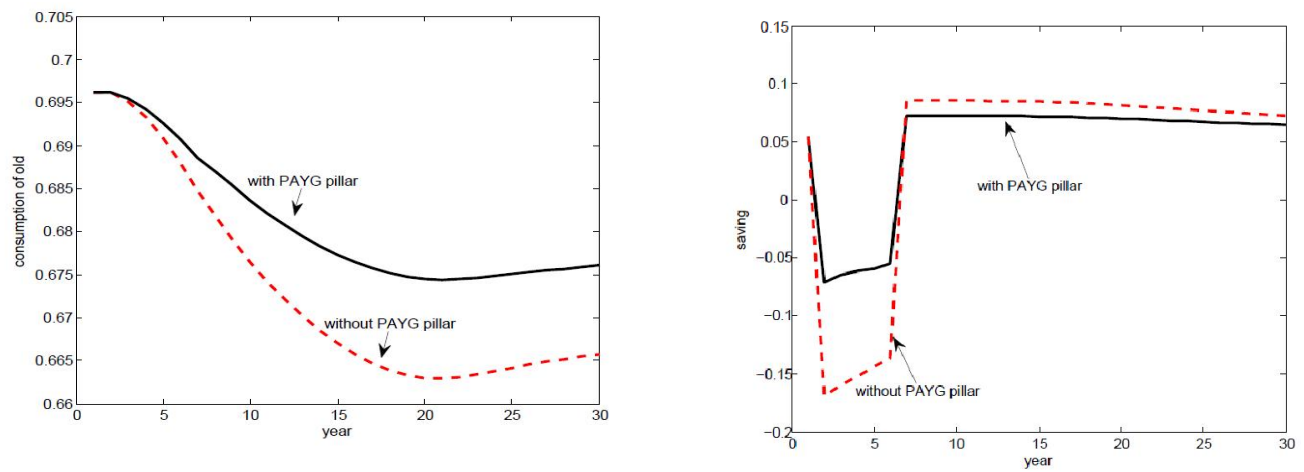

One sees from Figures 10 and 11 that the response of consumption of both young and old to the shock is larger in the situation without a PAYG pillar: Consumption in the adjustment periods is lower in that situation since the first pillar is not affected by the shock in the stock market - see also equation (29a). This also illustrates the advantage of a PAYG pillar under these circumstances. As can be seen from Figure 12, savings in the situation without the PAYG pillar decrease more because of the larger effect of the stock market crash. 


\subsection{Equity risk}

In previous simulations we did not consider equity risk. However, the actual equity return is volatile. From equation (22) one sees that the variance of the equity return affects the pension premium - the larger the variance of the equity return the higher the variance of $\tau_{t}^{p}$. Due to the impact of equity risk on the pension premium, both consumption and savings will be affected. We illustrate this by simulating the impact of varying equity return.

Let equity return follow a lognormal distribution (Draper and Westerhout, 2009). The expected equity return is $3.5 \%$. We draw 100 different stochastic paths and calculated the expected developments for the equity return with a standard deviation equal to 0.025 and $0.05 \square^{12}$ The five Figures below show the steady state path and the two expected developments of the equity return, pension premium, consumption of young, consumption of old and savings during 30 years.

In Figure 13 we can see that the time path of expected equity return is more volatile, the higher the standard deviation of the equity return is. Consistent with equation (22) the path of the pension premium then is more volatile too, as can be seen from Figure 14.

Comparing Figures 13 and 14 shows that when the equity return is higher than the equity return in the steady state, the pension premium is lower than the one in the steady state. This can be explained by the negative impact of the returns on pension wealth on the pension premium - see also equation (21).

Savings are also more volatile when the standard deviation of the equity return is higher, as is illustrated by Figure 15. Comparison of the latter with Figure 13 illustrates that the relation between savings and equity returns is positive. As we mentioned above, young

\footnotetext{
12 The data downloaded from the database of CRSP is used to calculate the standard deviation of the stock return each year from 1993 to 2009. According to the calculation the biggest standard deviation is 0.05 and the smallest is 0.025 .
} 
individuals pay a lower pension premium when equity return is higher, then they have more left to save..$^{13}$

Figure 13 The adjustment path of equity return

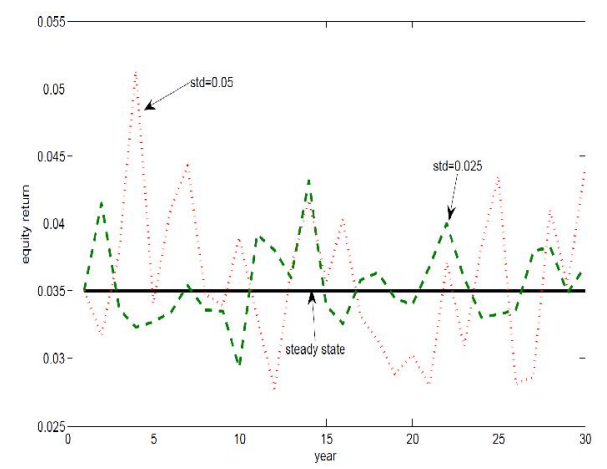

Figure 15 The adjustment path of savings

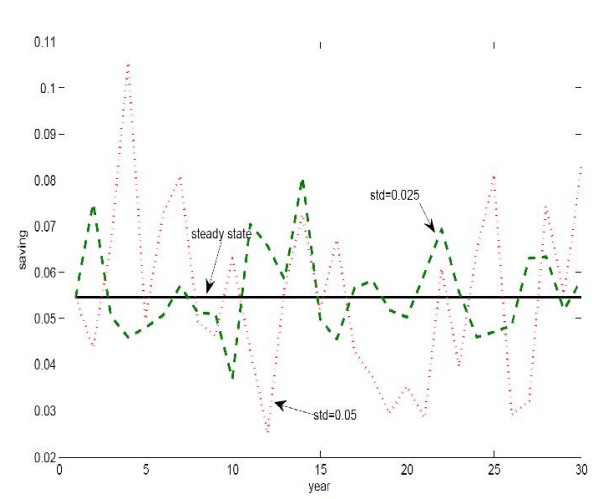

Figure 14 The adjustment path of the pension premium

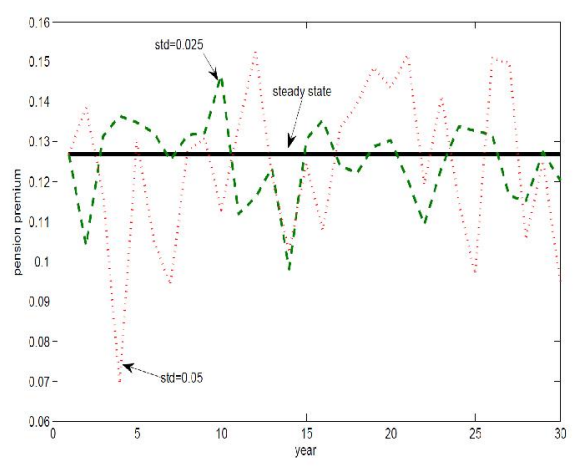

Figure 16 The adjustment path of consumption of young

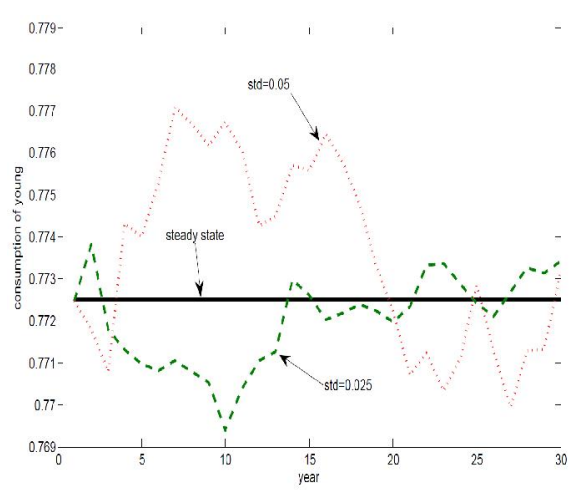

\footnotetext{
${ }^{13}$ In our model we do not consider the possibility of risk aversion.
} 
Figure 17 The adjustment path of consumption of old

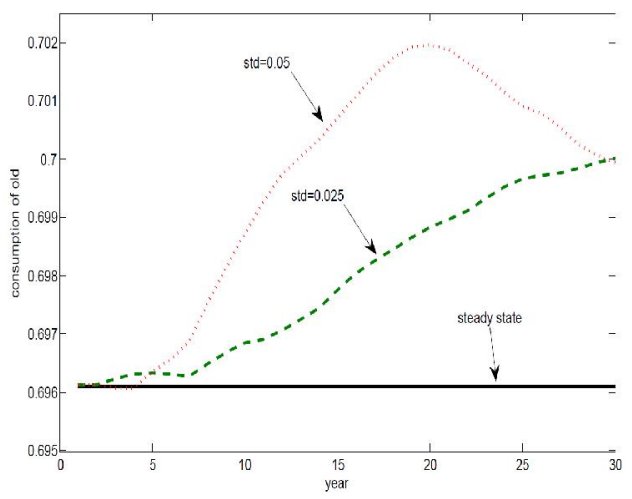

From Figure 16 one sees that the volatility of the consumption of the young also is higher the larger the standard deviation of the equity return, and the same phenomenon can be observed for consumption of the old in Figure 17. The relation between the consumption of the young and the old on the one hand, and equity return on the other is less clear, however.

The latter can be explained as follows. Consumption is proportional to total wealth. Total wealth is the sum of the financial wealth and the human capital.For the young, human capital is the sum of the present value of after-pension premium wage in the young period and the present value of pensions which is not affected by equity return. However, the pension premium paid for the pension fund is affected by equity return as mentioned above. Financial wealth is the savings accumulated in the previous periods, and equity return has an effect on savings as explained already in Figure 15. Figure 16 represents the average consumption of all 40 generations of young people. If the total wealth of a young generation is larger than the total wealth of the corresponding young generation in the steady state, consumption of young will increase. When more young generations have larger total wealth, consumption of young increases more.

The developments in Figure 16 can be explained using this logic. For example, from year 5 to year 20, consumption of young when the standard deviation is 0.05 is larger than 
consumption of young in the steady state. During these years the increase in consumption

of young from the young generations who have larger total wealth dominates the decrease in the consumption of young from the young generations who have smaller total wealth, which can be checked in Figures 14 and 15. In these years, the pension premiums are lower than the value in the steady state most of the time, which increases human capital. And savings are higher than in the steady state in most years, which increases financial wealth.

For the old, human capital is the present value of pensions which is not affected by equity return. Financial wealth is accumulated savings, which are affected by equity return as explained above. Figure 17 represents the average consumption of all 20 generations of old persons. If accumulated savings of a recent old generation are larger than accumulated savings of a recent old generation in the steady state, consumption of old will increase, assuming that the present value of the pension benefits is constant. When more old generations have larger accumulated savings, consumption of old increases more. The developments presented in Figure 17 then can be explained. For example from year 5 to year 20, consumption of old increases steadily when the standard deviation is 0.05 . This is consistent with the observation from Figure 15 that all recent old generations have larger accumulated savings than in the steady state.

In summary, we find that higher volatility of equity returns leads to more volatile consumption patterns of both generations and both the pensions and savings fluctuate in line with equity returns.

\section{Concluding remarks}

In this paper we model a three-pillar pension system in a small open economy with two overlapping generations. We examine how pension benefit ratios, returns on bonds and equity, the participation rate, the population growth rate, the survival rate, the inflation rate and the division of the pension premium between firms and workers affect the consumption of the young and the old, as well as savings, in the steady state. 
The model presented in this paper allows us to study the interaction of the three pillars under different exogenous (economic) shocks. For this purpose, the impact of ageing, inflation and a stock market crash has been simulated for the case of The Netherlands. The simulation results clearly demonstrate that the existence of the three-pillar system, notably the coexistence of a PAYG scheme and (private) pension savings, contributes to risk diversification - positively affecting pension benefits and consumption under various shocks. We show that the first pillar acts as a stabilising force in case of a stock market crash and inflation, whereas stabilisation is provided by the second and third pillar when the economy is affected by an ageing society.

Our findings also put the conclusions of the Commissie Toekomstbestendigheid Aanvullende Pensioenregelingen (2010) in perspective. It is true that the pension premium is also affected by ageing of the population, but - overall - to a much lesser extent than the PAYG tax rate. A substantial funded pension pillar is required, in particular in an ageing society, to continue to be able to provide adequate pension benefits. Scaling down funded pension schemes, as suggested by the Commissie, given the expected increase in the pension premium, might in the medium to long term only aggravate the problem. 


\section{REFERENCES}

Armstrong, A., Draper, D.A.G., Nibbelink, A.G.H. and Westerhout, E.W.M.T. (2007), Fiscal Prefunding in Response to Demographic Uncertainty, CPB Discussion Paper No. 85 .

Benkovskis, K. (2006), The effect of Latvian pension reform on savings and government budget, Baltic Journal of Economics, Vol. 6, 3-21.

Bonenkamp, J., Westerhout, E.W.M.T. en Vos, S.J. (2010), Commissie Toekomstbestendigheid Aanvullende Pensioenregelingen, CPB Memorandum, 1/2010/01.

Bonenkamp, J. and Westerhout, E.W.M.T. (2010), Intergenerational Risk Sharing and Labor Supply in Collective Funded Pension Schemes with Defined Benefits, $C P B$ Discussion Paper, No. 151.

Bonenkamp, J. and Van de Ven, M. (2006), A small stochastic model of a pension fund with endogenous saving, CPB Memorandum, No. 168.

Bovenberg, A.L. and Uhlig, H.F.H.V.S. (2006), Pension Systems and the Allocation of Macroeconomic Risk, Tilburg University, CentER Discussion Paper, No. 2006-101.

Broer, D. (2010), Macroeconomic Risks and Pension Returns, CPB Memorandum, No. 241.

Commissie Toekomstbestendigheid Aanvullende Pensioenregelingen (2010), Een sterke tweede pijler: Naar een toekomstbestendig stelsel van aanvullende pensioenen.

Deger, C. (2008), Pension reform in an OLG Model with Multiple Social Security Systems, ERC Working Papers in Economics, 08/05. 
De Kam, van der Lecq, C.A., S.G. , Sleijpen, O.C.H.M. en Steenbeek, O.W (2007), Sociale zekerheid: de AOW ziet Abraham, Jaarboek Overheidsfinanciën 2007, Wim Drees Stichting, Den Haag.

Draper, D.A.G. and Armstrong, A. (2007), GAMMA model, a simulation model for ageing, pensions and public finances, CPB Discussion Paper, No. 147.

Draper, D.A.G., Knaap, T. and Westerhout, E.W.M.T. (2003), Institutional Reform in the Dutch Pension Sector, CPB Discussion Paper.

Draper, D.A.G., and Westerhout, E.W.M.T.(2009), Privatizing pension: more than an interesting thought? CPB Discussion Paper, No. 201

Edwards, S. (1996), Why are Latin America's savings rates so low? An international comparative analysis, Journal of Develpment Economics, Vol. 51, 5-44.

Fanti, L. and Gori, L. (2008), Longevity and PAYG pension systems sustainability, Economics Bulletin, Vol. 10, No. 2, 1-8.

Groezen, B. , Meijdam, L. and Verbon, H. (2007), The case for Pay-as-you-go pensions in a service economy, Scottish Journal of Policitical Economy, Vol. 54, No. 2, 151-165.

Heer, B. and Irmen, A. (2009), Population, pensions and endogenous economic growth, Centre for Economic Policy Research, Discussion Paper, No. 7172.

Henin, P. Y. and Weitzenblum, Th. (2005), Welfare effects of alternative pension reforms: assessing the transition costs for French socio-occupational groups, Cambridge University Press, 4(3), 249-271.

Kemmerling, A. and Neugart, M. (2009), Financial market lobbies and pension reform, European Journal of Political Economy, 25, 163-173. 
Martins, O., Gonand, J.F. , Antolin, P. , de la Maisonneuve, C. and Yoo, K. (2005), The impact of ageing in demand, factor markets and growth, OECD Economics Department Working Papers, No. 420.

Masson, P.R. and Tryon, R.W. (1990), Macroeconomic effects of projected population aging in industrial countrie, IMF Working Papers, 90/5, International Monetary Fund.

Rahman, M. (2008), Demographic uncertainty and welfare in a life-cycle model under alternative public pension systems, CAEPR Working Paper, 2008-024.

Studiegroep Begrotingsruimte (2006), $12^{e}$ Rapport van de Studiegroep Begrotingsruimte: Vergrijzing en Houdbaarheid, Den Haag.

Verbic, M. (2007), Modelling the pension system in an overlapping-generations general equilibrium modeling framework, MPRA Paper, No. 10350.

World Bank (1994), Averting the Old Age Crisis: Policies to Protect the Old and Promote Growth, Oxford University Press, book-xiii, 402p. 
Appendix

\section{Deviation of results in Table 1}

In this part we presents details to clarify the roles of the public pension, the pension fund pension, the employer contribution to the pension premium, the inflation, the bonds

return, the equity return, the participation rate, the population growth rate and the survival rate.

1. The effects of the public pension

According to equations (27) and (28), we have that:

$$
\begin{aligned}
& \frac{\partial \tau^{g}}{\partial \xi^{g}}=\frac{\varepsilon}{(1+n) p}>0 \\
& \frac{\partial \tau^{p}}{\partial \xi^{g}}=0
\end{aligned}
$$

Which show that the public pension has positive effect on the PAYG-tax rate and no effect on the pension premium.

According to equations (23), (24) and (25), we have that:

$$
\begin{gathered}
\frac{\partial c^{y}}{\partial \xi^{g}}=\frac{\frac{\varepsilon}{1+n} w}{\varepsilon\left[\gamma\left(1+r^{b}\right)\right]^{\frac{1}{\theta}}+\left(1+r^{b}\right)}\left[(1+g)(1+n)-\left(1+r^{b}\right)\right] \stackrel{<}{>} 0 \\
\frac{\partial c^{o}}{\partial \xi^{g}}=\frac{\left[\gamma\left(1+r^{b}\right)\right]^{\frac{1}{\theta}} \frac{\varepsilon}{1+n} w}{\varepsilon\left[\gamma\left(1+r^{b}\right)\right]^{\frac{1}{\theta}}+\left(1+r^{b}\right)}\left[(1+g)(1+n)-\left(1+r^{b}\right)\right] \leq 0 \\
>
\end{gathered}
$$




$$
\frac{\partial s}{\partial \xi^{g}}=-\frac{\varepsilon w}{1+n} \frac{\varepsilon\left[\gamma\left(1+r^{b}\right)\right]^{\frac{1}{\theta}}+(1+g)(1+n)}{\varepsilon\left[\gamma\left(1+r^{b}\right)\right]^{\frac{1}{\theta}}+\left(1+r^{b}\right)}<0
$$

Which show that the effects of the public pension on the consumption in the young period and the consumption in the old period depend on whether $\left(1+r^{b}\right)>(1+\mathrm{g})(1+\mathrm{n})$ or not $\left(1+r^{b}\right)<(1+\mathrm{g})(1+\mathrm{n})$. If $\left(1+r^{b}\right)>(1+\mathrm{g})(1+\mathrm{n})$, an increase in the public pension decreases the consumption in the young period and the consumption in the old period. The relation between the public pension and the saving is negative.

2. The effects of the pension fund pension

According to equations (27) and (28), the effects of the pension fund pension on the PAYG-tax rate and on the pension premium are:

$$
\begin{aligned}
& \frac{\partial \tau^{g}}{\partial \xi^{p}}=0 \\
& \frac{\partial \tau^{p}}{\partial \xi^{p}}=\frac{\varepsilon}{1+r^{e}}>0
\end{aligned}
$$

Thus the pension fund pension does not affect the PAYG-tax rate and the effect of the pension fund pension on the pension premium is positive.

According to equations (23), (24) and (25), the effects of the pension fund pension on the consumption in the young period, the consumption in the old period and the saving are:

$$
\begin{aligned}
& \frac{\partial c^{y}}{\partial \xi^{p}}=\frac{\frac{\varepsilon p w}{1+r^{e}}}{\varepsilon\left[\gamma\left(1+r^{b}\right)\right]^{\frac{1}{\theta}}+\left(1+r^{b}\right)}\left[\left(1+r^{e}\right)-(1-\beta)\left(1+r^{b}\right)\right] \\
& -(1-\alpha) A^{\frac{1}{1-\alpha}}\left(\frac{\alpha}{r^{k}}\right)^{\frac{\alpha}{1-\alpha}} \frac{\beta}{\left(1+\beta \tau^{p}\right)^{2}} \frac{\varepsilon}{1+r^{e}} \Lambda \leq 0
\end{aligned}
$$




$$
\begin{aligned}
& \frac{\partial c^{o}}{\partial \xi^{p}}=\left[\gamma\left(1+r^{b}\right)\right]^{\frac{1}{\theta}}\left\{\frac{\frac{\varepsilon p w}{1+r^{e}}}{\varepsilon\left[\gamma\left(1+r^{b}\right)\right]^{\frac{1}{\theta}}+\left(1+r^{b}\right)}\left[\left(1+r^{e}\right)-(1-\beta)\left(1+r^{b}\right)\right]\right. \\
& \left.-(1-\alpha) A^{\frac{1}{1-\alpha}}\left(\frac{\alpha}{r^{k}}\right)^{\frac{\alpha}{1-\alpha}} \frac{\beta}{\left(1+\beta \tau^{p}\right)^{2}} \frac{\varepsilon}{1+r^{e}} \Lambda\right\} \frac{<}{>} 0 \\
& \frac{\partial s}{\partial \xi^{p}}=\frac{-\frac{\varepsilon p w}{1+r^{e}}\left[\gamma\left(1+r^{b}\right)\right]^{\frac{1}{\theta}}(1-\beta)-\varepsilon p w}{\varepsilon\left[\gamma\left(1+r^{b}\right)\right]^{\frac{1}{\theta}}+\left(1+r^{b}\right)}+\left\{\left[1-\tau^{g}-(1-\beta) \tau^{p}\right] p-\Lambda\right\} \frac{\partial w}{\partial \xi^{p}}<0 \\
& \text { With } \frac{\partial w}{\partial \xi^{p}}=-(1-\alpha) A^{\frac{1}{1-\alpha}}\left(\frac{\alpha}{r^{k}}\right)^{\frac{\alpha}{1-\alpha}} \frac{\beta}{\left(1+\beta \tau^{p}\right)^{2}} \frac{\varepsilon}{1+r^{e}}<0
\end{aligned}
$$

Thus when $\left(1+r^{e}\right)<(1-\beta)\left(1+r^{b}\right)$ the effects of the pension fund pension on the consumption in the young period and the consumption are negative. And the effect of the pension fund pension on the saving is negative.

3. The effects of the employer contribution to the pension premium

According to equations (27) and (28), the effects of the employer contribution to the PAYG-tax rate and on the pension premium are given by:

$$
\begin{aligned}
& \frac{\partial \tau^{g}}{\partial \beta}=0 \\
& \frac{\partial \tau^{p}}{\partial \beta}=0
\end{aligned}
$$

Which show that the employer contribution to the pension premium has no effect on the PAYG-tax rate and on the pension premium. According to equations (23), (24) and (25), the effects of the employer contribution to the pension premium on the consumption in the young period, on the consumption in the old period and the saving are given by: 


$$
\begin{aligned}
& \frac{\partial c^{y}}{\partial \beta}=\frac{\left(1+r^{b}\right) \tau^{p} p w}{\varepsilon\left[\gamma\left(1+r^{b}\right)\right]^{\frac{1}{\theta}}+\left(1+r^{b}\right)}-(1-\alpha) A^{\frac{1}{1-\alpha}}\left(\frac{\alpha}{r^{k}}\right)^{\frac{\alpha}{1-\alpha}} \frac{\tau^{p}}{\left(1+\beta \tau^{p}\right)^{2}} \Lambda \leq 0 \\
& \frac{\partial c^{o}}{\partial \beta}=\left[\gamma\left(1+r^{b}\right)\right]^{\frac{1}{\theta}}\left[\frac{\left(1+r^{b}\right) \tau^{p} p w}{\varepsilon\left[\gamma\left(1+r^{b}\right)\right]^{\frac{1}{\theta}}+\left(1+r^{b}\right)}-(1-\alpha) A^{\frac{1}{1-\alpha}}\left(\frac{\alpha}{r^{k}}\right)^{\frac{\alpha}{1-\alpha}} \frac{\tau^{p}}{\left(1+\beta \tau^{p}\right)^{2}} \Lambda\right] \leq 0 \\
& \frac{\partial s}{\partial \beta}=\varepsilon\left[\gamma\left(1+r^{b}\right)\right]^{\frac{1}{\theta}} \frac{\tau^{p} p w}{\varepsilon\left[\gamma\left(1+r^{b}\right)\right]^{\frac{1}{\theta}}+\left(1+r^{b}\right)}-\Lambda \frac{\tau^{p} w}{1+\beta \tau^{p}} \leq 0
\end{aligned}
$$

Thus the effects of the employer contribution to the pension premium on the consumptions and savings cannot be derived explicitly.

\section{The effects of the inflation}

In order to identify the effect of the inflation rate $\pi$, we need to analyze it in two situations. The first is the expected inflation $\pi^{e}$ is equal to the actual inflation $\pi$, which is possible when the actual inflation rate is constant. The other is the actual inflation $\pi$ changes unexpectedly, which means the expected inflation $\pi^{e}$ is not equal to the actual inflation $\pi$.

In the first situation, according to equations (23), (24), (25), (27) and (28), it is obvious that when the expected inflation $\pi^{e}$ is equal to the actual inflation $\pi$, the inflation has no effect on the consumptions, saving, PAYG-tax rate and pension premium.

When the actual inflation $\pi$ changes unexpectedly, equations (23), (24), (25), (27) and (28) are rewritten as:

$$
\begin{aligned}
& c^{y}=\Lambda w \\
& c^{o}=[\gamma(1+\lambda)]^{\frac{1}{\theta}} \Lambda w \\
& s=\left\{\left[1-\tau^{g}-(1-\beta) \tau^{p}\right] p-\Lambda\right\} w
\end{aligned}
$$


Where $\Lambda=\frac{(1+\lambda)\left[1-\tau^{g}-(1-\beta) \tau^{p}\right] p+\varepsilon\left[\xi^{p} p+\xi^{g}(1+g)\right]}{\varepsilon[\gamma(1+\lambda)]^{\frac{1}{\theta}}+(1+\lambda)} \quad 1+\lambda=\frac{\left(1+r^{b}\right)\left(1+\pi^{e}\right)}{1+\pi}$

$\tau^{g}=\frac{\varepsilon \xi^{g}}{(1+n) p}$

$\tau^{p}=\frac{(1+\pi) \varepsilon \xi^{p}}{\left(1+r^{e}\right)\left(1+\pi^{e}\right)}$

Differentiating equations (A19) and (A20) with respect to the actual inflation rate $\pi$ :

$$
\begin{aligned}
& \frac{\partial \tau^{g}}{\partial \pi}=0 \\
& \frac{\partial \tau^{p}}{\partial \pi}=\frac{\varepsilon \xi^{p}}{\left(1+r^{e}\right)\left(1+\pi^{e}\right)}>0
\end{aligned}
$$

Differentiating equations (A16), (A17) and (A18) with respect to the actual inflation rate $\pi$ :

$$
\begin{aligned}
& \frac{\partial c^{y}}{\partial \pi}=\left\{\frac{\left[1-\tau^{g}-(1-\beta) \tau^{p}\right] p \frac{\partial(1+\lambda)}{\partial \pi}-(1+\lambda)(1-\beta) p \frac{\partial \tau^{p}}{\partial \pi}}{\varepsilon[\gamma(1+\lambda)]^{\frac{1}{\theta}}+(1+\lambda)}-\right. \\
& \left.\frac{\Lambda\left\{\frac{\varepsilon \gamma}{\theta}[\gamma(1+\lambda)]^{\frac{1}{-}-1}+1\right\} \frac{\partial(1+\lambda)}{\partial \pi}}{\varepsilon[\gamma(1+\lambda)]^{\frac{1}{\theta}}+(1+\lambda)}\right\} w+\Lambda \frac{\partial w}{\partial \pi} \leq 0 \\
& \frac{\partial c^{o}}{\partial \pi}=\frac{\gamma}{\theta}[\gamma(1+\lambda)]^{\frac{1}{\theta}-1} \frac{\partial(1+\lambda)}{\partial \pi} \Lambda w+[\gamma(1+\lambda)]^{\frac{1}{\theta}} \\
& \left\{\frac{\left[1-\tau^{g}-(1-\beta) \tau^{p}\right] p \frac{\partial(1+\lambda)}{\partial \pi}-(1+\lambda)(1-\beta) p \frac{\partial \tau^{p}}{\partial \pi}}{\varepsilon[\gamma(1+\lambda)]^{\frac{1}{\theta}}+(1+\lambda)}\right. \\
& \left.\frac{\Lambda\left\{\frac{\varepsilon \gamma}{\theta}[\gamma(1+\lambda)]^{\frac{1}{-}-1}+1\right\} \frac{\partial(1+\lambda)}{\partial \pi}}{\varepsilon}\right\} w+[\gamma(1+\lambda)]^{\frac{1}{\theta}} \Lambda \frac{\partial w}{\partial \pi}<0 \\
& \varepsilon[\gamma(1+\lambda)]^{\frac{1}{\theta}}+(1+\lambda)
\end{aligned}
$$




$$
\begin{aligned}
& \frac{\partial s}{\partial \pi}=-(1-\beta) p w \frac{\partial \tau^{p}}{\partial \pi}+\left[1-\tau^{g}-(1-\beta) \tau^{p}\right] p \frac{\partial w}{\partial \pi}- \\
& \left\{\frac{\left[1-\tau^{g}-(1-\beta) \tau^{p}\right] p \frac{\partial(1+\lambda)}{\partial \pi}-(1+\lambda)(1-\beta) p \frac{\partial \tau^{p}}{\partial \pi}}{\varepsilon[\gamma(1+\lambda)]^{\frac{1}{\theta}}+(1+\lambda)}-\right. \\
& \left.\frac{\Lambda\left\{\frac{\varepsilon \gamma}{\theta}[\gamma(1+\lambda)]^{\frac{1}{\theta}-1}+1\right\} \frac{\partial(1+\lambda)}{\partial \pi}}{\varepsilon[\gamma(1+\lambda)]^{\frac{1}{\theta}}+(1+\lambda)}\right\} w-\Lambda \frac{\partial w}{\partial \pi}<0
\end{aligned}
$$

Where $\frac{\partial(1+\lambda)}{\partial \pi}=-\frac{\left(1+r^{b}\right)\left(1+\pi^{e}\right)}{(1+\pi)^{2}}<0$

$$
\frac{\partial w}{\partial \pi}=-(1-\alpha) A^{\frac{1}{1-\alpha}}\left(\frac{\alpha}{r^{k}}\right)^{\frac{\alpha}{1-\alpha}} \frac{\beta}{\left(1+\beta \tau^{p}\right)^{2}} \frac{\partial \tau^{p}}{\partial \pi}<0
$$

According to equation (A21), the PAYG-tax rate does not respond to the actual inflation rate. The actual inflation rate affects the pension premium positively according to equation (A22). And the effect of the actual inflation rate on the consumption in the young period is ambiguous according to equation (A23). According to equations (A24) and (A25), the effects of the actual inflation rate on the consumption in the old period and the saving are negative.

5. The effects of the bonds return

According to equations (27) and (28), the effects of the bonds return on the PAYG-tax rate and on the pension premium are given by:

$$
\begin{aligned}
& \frac{\partial \tau^{g}}{\partial r^{b}}=0 \\
& \frac{\partial \tau^{p}}{\partial r^{b}}=0
\end{aligned}
$$

Which show that the bonds return has no effect on the PAYG-tax rate and on the pension premium. 
According to equations (23), (24) and (25), the effects of the bonds return on the consumption in the young period, on the consumption in the old period and the saving are given by:

$$
\begin{aligned}
& \frac{\partial c^{y}}{\partial r^{b}}=\frac{\left[1-\tau^{g}-(1-\beta) \tau^{p}\right] \varepsilon p w\left[\gamma\left(1+r^{b}\right)\right]^{\frac{1}{\theta}}}{\left\{\varepsilon\left[\gamma\left(1+r^{b}\right)\right]^{\frac{1}{\theta}}+\left(1+r^{b}\right)\right\}^{2}}\left(1-\frac{1}{\theta}\right)- \\
& \frac{\varepsilon\left[\xi^{p} p+\xi^{g}(1+g)\right]}{\left\{\varepsilon\left[\gamma\left(1+r^{b}\right)\right]^{\frac{1}{\theta}}+\left(1+r^{b}\right)\right\}^{2}}\left\{\frac{\varepsilon \gamma}{\theta}\left[\gamma\left(1+r^{b}\right)\right]^{\frac{1}{\theta}-1}+1\right\} w \leq 0 \\
& \frac{\partial c^{o}}{\partial r^{b}}=\frac{\left[1-\tau^{g}-(1-\beta) \tau^{p}\right] p w}{\left\{\varepsilon\left[\gamma\left(1+r^{b}\right)\right]^{\frac{1}{\theta}}+\left(1+r^{b}\right)\right\}^{2}}\left\{\frac{1+r^{b}}{\theta}\left[\gamma\left(1+r^{b}\right)\right]^{\frac{1}{\theta}}+\varepsilon\left[\gamma\left(1+r^{b}\right)\right]^{\frac{2}{\theta}}\right\}+ \\
& \frac{\varepsilon w\left[\xi^{p} p+\xi^{g}(1+g)\right]}{\left\{\varepsilon\left[\gamma\left(1+r^{b}\right)\right]^{\frac{1}{\theta}}+\left(1+r^{b}\right)\right\}^{2}}\left(\frac{1}{\theta}-1\right)\left[\gamma\left(1+r^{b}\right)\right]^{\frac{1}{\theta}}<0 \\
& \frac{\partial s}{\partial r^{b}}=\frac{\left[1-\tau^{g}-(1-\beta) \tau^{p}\right] \varepsilon p w\left[\gamma\left(1+r^{b}\right)\right]^{\frac{1}{\theta}}}{\left\{\varepsilon\left[\gamma\left(1+r^{b}\right)\right]^{\frac{1}{\theta}}+\left(1+r^{b}\right)\right\}^{2}}\left(\frac{1}{\theta}-1\right)+ \\
& \frac{\varepsilon\left[\xi^{p} p+\xi^{g}(1+g)\right]}{\left\{\varepsilon\left[\gamma\left(1+r^{b}\right)\right]^{\frac{1}{\theta}}+\left(1+r^{b}\right)\right\}^{2}}\left\{\frac{\varepsilon \gamma}{\theta}\left[\gamma\left(1+r^{b}\right)\right]^{\frac{1}{\theta}-1}+1\right\} w \leq 0
\end{aligned}
$$

Therefore, if $\frac{1}{\theta}>1$, then $\frac{\partial c^{y}}{\partial r^{b}}<0, \frac{\partial c^{o}}{\partial r^{b}}>0, \frac{\partial s}{\partial r^{b}}>0$ and the effect of the bonds return on the consumption in the young period is negative, the effects of the bonds return on the consumption in the old period and the saving are positive.

6. The effects of the equity return

According to equations (27) and (28), the effects of the equity return on the PAYG-tax rate and on the pension premium are found by evaluating the partial derivatives:

$$
\frac{\partial \tau^{g}}{\partial r^{e}}=0
$$


$\frac{\partial \tau^{p}}{\partial r^{e}}=-\frac{\varepsilon \xi^{p}}{\left(1+r^{e}\right)^{2}}<0$

Which show that the equity return does not affect the PAYG-tax rate and the equity return affects the pension premium negatively.

According to equations (23), (24) and (25), the effects of the equity return on the consumption in the young period, the consumption in the old period and the saving are found by evaluating the partial derivatives:

$\frac{\partial c^{y}}{\partial r^{e}}=\frac{-\left(1+r^{b}\right)(1-\beta) p w \frac{\partial \tau^{p}}{\partial r^{e}}}{\varepsilon\left[\gamma\left(1+r^{b}\right)\right]^{\frac{1}{\theta}}+\left(1+r^{b}\right)}+\Lambda \frac{\partial w}{\partial r^{e}}>0$

$\frac{\partial c^{o}}{\partial r^{e}}=\left[\gamma\left(1+r^{b}\right)\right]^{\frac{1}{\theta}}\left\{\frac{-\left(1+r^{b}\right)(1-\beta) p w \frac{\partial \tau^{p}}{\partial r^{e}}}{\varepsilon\left[\gamma\left(1+r^{b}\right)\right]^{\frac{1}{\theta}}+\left(1+r^{b}\right)}+\Lambda \frac{\partial w}{\partial r^{e}}\right\}>0$

$\frac{\partial s}{\partial r^{e}}=\frac{-\varepsilon\left[\gamma\left(1+r^{b}\right)\right]^{\frac{1}{\theta}}(1-\beta) p w}{\varepsilon\left[\gamma\left(1+r^{b}\right)\right]^{\frac{1}{\theta}}+\left(1+r^{b}\right)} \frac{\partial \tau^{p}}{\partial r^{e}}+\left\{\left[1-\tau^{g}-(1-\beta) \tau^{p}\right] p-\Lambda\right\} \frac{\partial w}{\partial r^{e}}>0$

Where $\frac{\partial w}{\partial r^{e}}=-(1-\alpha) A^{\frac{1}{1-\alpha}}\left(\frac{\alpha}{r^{k}}\right)^{\frac{\alpha}{1-\alpha}} \frac{\beta \frac{\partial \tau^{p}}{\partial r^{e}}}{\left(1+\beta \tau^{p}\right)^{2}}>0$

Which show that the consumption in the young period, the consumption in the old period and the saving respond positively to the equity return.

7. The effects of the participation rate

Differentiating equations (27) and (28) with respect to the participation rate $p$ :

$\frac{\partial \tau^{g}}{\partial p}=-\frac{\varepsilon \xi^{g}}{(1+n) p^{2}}<0$ 


$$
\frac{\partial \tau^{p}}{\partial p}=0
$$

We can conclude that the participation rate has a negative effect on PAYG-tax rate and has no effect on the pension premium.

Differentiating equations (23), (24) and (25):

$$
\begin{aligned}
& \frac{\partial c^{y}}{\partial p}=\frac{-\left(1+r^{b}\right) p \frac{\partial \tau^{g}}{\partial p}+\left(1+r^{b}\right)\left[1-\tau^{g}-(1-\beta) \tau^{p}\right]+\varepsilon \xi^{p}}{\varepsilon\left[\gamma\left(1+r^{b}\right)\right]^{\frac{1}{\theta}}+\left(1+r^{b}\right)} w>0 \\
& \frac{\partial c^{o}}{\partial p}=\left[\gamma\left(1+r^{b}\right)\right]^{\frac{1}{\theta}} \frac{-\left(1+r^{b}\right) p \frac{\partial \tau^{g}}{\partial p}+\left(1+r^{b}\right)\left[1-\tau^{g}-(1-\beta) \tau^{p}\right]+\varepsilon \xi^{p}}{\varepsilon\left[\gamma\left(1+r^{b}\right)\right]^{\frac{1}{\theta}}+\left(1+r^{b}\right)} w>0 \\
& \frac{\partial s}{\partial p}=\frac{\varepsilon\left[\gamma\left(1+r^{b}\right)\right]^{\frac{1}{\theta}}\left[1-\tau^{g}-(1-\beta) \tau^{p}\right]-\varepsilon \xi^{p}}{\varepsilon\left[\gamma\left(1+r^{b}\right)\right]^{\frac{1}{\theta}}+\left(1+r^{b}\right)} w>0
\end{aligned}
$$

Therefore, the effect of the participation rate on the consumptions and saving are positive.

8. The effects of the population growth rate

Differentiating equations (27) and (28) with respect to the population growth rate $n$ :

$$
\begin{aligned}
& \frac{\partial \tau^{g}}{\partial n}=-\frac{\varepsilon p \xi^{g}}{(1+n)^{2}}<0 \\
& \frac{\partial \tau^{p}}{\partial n}=0
\end{aligned}
$$

Thus, the population growth rate has a negative impact on the PAYG-tax rate.

The population growth rate does not affect the pension premium.

Differentiating equations (23), (24) and (25) with respect to the population grow rate $n$ : 


$$
\begin{aligned}
& \frac{\partial c^{y}}{\partial n}=-\frac{\left(1+r^{b}\right) p w}{\varepsilon\left[\gamma\left(1+r^{b}\right)\right]^{\frac{1}{\theta}}+\left(1+r^{b}\right)} \frac{\partial \tau^{g}}{\partial n}>0 \\
& \frac{\partial c^{o}}{\partial n}=-\left[\gamma\left(1+r^{b}\right)\right]^{\frac{1}{\theta}} \frac{\left(1+r^{b}\right) p w}{\varepsilon\left[\gamma\left(1+r^{b}\right)\right]^{\frac{1}{\theta}}+\left(1+r^{b}\right)} \frac{\partial \tau^{g}}{\partial n}>0 \\
& \frac{\partial s}{\partial n}=-\frac{\varepsilon\left[\gamma\left(1+r^{b}\right)\right]^{\frac{1}{\theta}} p w}{\varepsilon\left[\gamma\left(1+r^{b}\right)\right]^{\frac{1}{\theta}}+\left(1+r^{b}\right)} \frac{\partial \tau^{g}}{\partial n}>0
\end{aligned}
$$

Thus, the population growth rate has positive impacts on the consumption in the young period, the consumption in the old period and the saving.

9. The effects of the survival rate

Differentiating equations (27) and (28) with respect to the survival rate $\varepsilon$ :

$$
\begin{aligned}
& \frac{\partial \tau^{g}}{\partial \varepsilon}=\frac{\xi^{g}}{(1+n) p}>0 \\
& \frac{\partial \tau^{p}}{\partial \varepsilon}=\frac{\xi^{p}}{1+r^{e}}>0
\end{aligned}
$$

Which shows that the impacts of the survival rate on the PAYG-tax rate and on the pension premium are both positive.

Differentiating equations (23), (24) and (25) with respect to the survival rate $\varepsilon$ :

$$
\begin{aligned}
& \frac{\partial c^{y}}{\partial \varepsilon}=\frac{\left(1+r^{b}\right)\left[-\frac{\partial \tau^{g}}{\partial \varepsilon}-(1-\beta) \frac{\partial \tau^{p}}{\partial \varepsilon}\right] p w}{\varepsilon\left[\gamma\left(1+r^{b}\right)\right]^{\frac{1}{\theta}}+\left(1+r^{b}\right)}- \\
& \frac{\left(1+r^{b}\right)\left[\gamma\left(1+r^{b}\right)\right]^{\frac{1}{\theta}}\left[1-\tau^{g}-(1-\beta) \tau^{p}\right] p w-\left[\xi^{p} p+\xi^{g}(1+g)\right]\left(1+r^{b}\right) w}{\left\{\varepsilon\left[\gamma\left(1+r^{b}\right)\right]^{\frac{1}{\theta}}+\left(1+r^{b}\right)\right\}^{2}}+\Lambda \frac{\partial w}{\partial \varepsilon}<0
\end{aligned}
$$




$$
\begin{aligned}
& \frac{\partial c^{o}}{\partial \varepsilon}=\left[\gamma\left(1+r^{b}\right)\right]^{\frac{1}{\theta}}\left\{\frac{\left(1+r^{b}\right)\left[-\frac{\partial \tau^{g}}{\partial \varepsilon}-(1-\beta) \frac{\partial \tau^{p}}{\partial \varepsilon}\right] p w}{\varepsilon\left[\gamma\left(1+r^{b}\right)\right]^{\frac{1}{\theta}}+\left(1+r^{b}\right)}-\right. \\
& \left.\frac{\left(1+r^{b}\right)\left[\gamma\left(1+r^{b}\right)\right]^{\frac{1}{\theta}}\left[1-\tau^{g}-(1-\beta) \tau^{p}\right] p w-\left[\xi^{p} p+\xi^{g}(1+g)\right]\left(1+r^{b}\right) w}{\left\{\varepsilon\left[\gamma\left(1+r^{b}\right)\right]^{\frac{1}{\theta}}+\left(1+r^{b}\right)\right\}^{2}}+\Lambda \frac{\partial w}{\partial \varepsilon}\right\}<0
\end{aligned}
$$

$$
\begin{aligned}
& \frac{\partial s}{\partial \varepsilon}=\frac{\varepsilon\left[\gamma\left(1+r^{b}\right)\right]^{\frac{1}{\theta}}\left[1-\tau^{g}-(1-\beta) \tau^{p}\right] p-\varepsilon\left[\xi^{p} p+\xi^{g}(1+g)\right]}{\varepsilon\left[\gamma\left(1+r^{b}\right)\right]^{\frac{1}{\theta}}+\left(1+r^{b}\right)} \frac{\partial w}{\partial \varepsilon} \\
& -\frac{\varepsilon\left[\gamma\left(1+r^{b}\right)\right]^{\frac{1}{\theta}}\left[\frac{\partial \tau^{g}}{\partial \varepsilon}+(1-\beta) \frac{\partial \tau^{p}}{\partial \varepsilon}\right] p w}{\varepsilon\left[\gamma\left(1+r^{b}\right)\right]^{\frac{1}{\theta}}+\left(1+r^{b}\right)}+ \\
& \frac{\left(1+r^{b}\right)\left[\gamma\left(1+r^{b}\right)\right]^{\frac{1}{\theta}}\left[1-\tau^{g}-(1-\beta) \tau^{p}\right] p w-\left[\xi^{p} p+\xi^{g}(1+g)\right]\left(1+r^{b}\right) w}{\left\{\varepsilon\left[\gamma\left(1+r^{b}\right)\right]^{\frac{1}{\theta}}+\left(1+r^{b}\right)\right\}^{2}}<0
\end{aligned}
$$

Where $\frac{\partial w}{\partial \varepsilon}=-\frac{\beta w}{1+\beta \tau^{p}} \frac{\partial \tau^{p}}{\partial \varepsilon}<0$

Although the impacts of the survival rate on the consumptions and saving cannot be derived explicitly but with sensible values of the parameters, the effects on the consumptions and saving should be negative.

\section{A continuous time version of the model}

In this part we present how the two-period discrete OLG model is transformed to a continuous-time model, on which the simulations in section 4 are based. In the continuous-time model, the firms and the public sector are modeled in the same way as in the two-period discrete OLG model. The models for consumer behaviour and the pension fund are adapted as follows: 


\section{Consumers}

The model consists of overlapping generations of consumers. Each year $N$ young people enter the economy and each year $N$ people die. This means at each year, entries and deaths exactly match and so the total population in the economy is constant over time. Moreover, the young people enter the economy at the age of 25 and retire at the age of 65 . Therefore persons remain young for 40 years. And the persons die at the age 85 . In this case we know the ratio of the old to the young in the economy follows from:

$\varepsilon \int_{25}^{65} N d v=\int_{65}^{85} N d v \rightarrow \varepsilon=\frac{1}{2}$

Hence an increase in the age of death, other things constant, leads to a higher value of . The young persons, who participate in the labor market at a rate $p(0<p \leq 1)$, earn a real wage income $w_{t}$, from which they contribute to the public sector and the pension fund at rates $\tau^{g}$ and $(1-\beta) \tau^{p}$, respectively. Net income then is spent on consumption and asset accumulation. When old, the people do not work, but receive a public pension $\eta^{g}$ and a pension $\eta^{p}$ from the pension fund ${ }^{14}$ A person who enters the economy at time $v$ therefore faces the following lifetime budget constraint at time $t \leq v+60$.

$$
A(v, t)+\bar{W}(v, t)=\int_{t}^{v+60} c(v, s) e^{-R(t, s)} d s \quad v \leq t \leq v+60
$$

with

$$
\begin{array}{cc}
\bar{W}(v, t)=\int_{t}^{v+40}\left[\left(1-\tau^{g}(s)-(1-\beta) \tau^{p}(s)\right) p w(s)\right] e^{-R(t, s)} d s+\int_{v+40}^{v+60}\left[\eta^{g}(s)+\eta^{p}(s)\right] e^{-R(t, s)} d s \\
\bar{W}(v, t)=\int_{t}^{v+60}\left[\eta^{g}(s)+\eta^{p}(s)\right] e^{-R(t, s)} d s & v \leq t \leq v+40
\end{array}
$$

\footnotetext{
${ }^{14}$ Actually, only those who have worked when young receive a pension, but in our aggregate analysis we take that into account by including the participation rate.
} 
Here $c(v, s)$ is consumption at time $s$ for a person entering at time $v$ and $R(t, s)=\int_{t}^{s} r(u) d u$ is the compound factor between $t$ and $s$, where $r(u)$ is the interest rate. $A(v, t)$ is the asset of the person and $\bar{W}(v, t)$ her human capital. For the young persons $(t-40 \leq v \leq t), \bar{W}(v, t)$ is the sum of the present value of after-pension premium wage in the young period and the present value of pensions, see equation (A51a). For the old persons $(t-60 \leq v<t-40)$ at time $\mathrm{t}, \bar{W}(v, t)$ is the present value of pensions, see equation (A51b).

Thus the budget constraint (A51) states that lifetime consumption cannot exceed the value of the human and financial capital.

Given the budget constraints (A51), individuals maximise the remaining lifetime utility.

$$
E U(v, t)=\int_{t}^{v+60} \frac{c(v, s)^{1-\theta}}{1-\theta} e^{-\rho(s-t)} d s
$$

where $\rho$ measures the rate of time preference ${ }^{15}$ and $1 / \theta>0$ is the elasticity of intertemporal substitution. Maximising equation (A52) subject to the budget constraints results in the following first-order condition

$c(v, s)^{-\theta} e^{-\rho(s-t)}=\lambda(t) e^{-R(t, s)}$

In this equation $c(v, s)^{-\theta}$ is the marginal utility of time $s$ consumption, and $\lambda(t)$ measures the marginal utility of lifetime wealth. But $\lambda(t)$ for the young is different from the one for the old because of different budget constraints. Equation (A53) shows that consumption is chosen at each time to equate the discounted marginal utilities of consumption and lifetime wealth. Differentiating (A53) with respect to $s$, the consumption Euler equation is derived.

${ }^{15}$ The rate of time preference is $1.3 \%$ on a year basis. $\mathrm{CPB}(2007)$. 
$\frac{\varepsilon(v, s)}{c(v, s)}=\frac{1}{\theta}[r(s)-\rho]$

From equation (A53), if $s=t$

$$
c(v, t)=\lambda(t)^{-\frac{1}{\theta}}
$$

By incorporating (A55) into (A53) we find

$$
c(v, s)^{-\theta} e^{-\rho(s-t)}=c(v, t)^{-\theta} e^{-R(t, s)}=c(v, t)^{-\theta} e^{-\theta R(t, s)} \cdot e^{-(1-\theta) R(t, s)}
$$

hence,

$$
\begin{aligned}
& \int_{t}^{v+60} c(v, t)^{\theta} e^{-\rho(s-t)} e^{(1-\theta) R(t, s)} d s=\int_{t}^{v+60} c(v, s)^{\theta} e^{-\theta R(t, s)} d s \\
& {[A(v, t)+\bar{W}(v, t)]^{\theta}=\int_{t}^{v+60} c(v, s)^{\theta} e^{-\theta R(t, s)} d s}
\end{aligned}
$$

Using equation (A58) and since for constant $r$ we have $R(t, s)=r(s-t)$ :

$$
\int_{t}^{v+60} e^{[(1-\theta) \cdot r-\rho](s-t)} d s c(v, t)^{\theta}=\frac{\left[e^{[(1-\theta) \cdot r-\rho](v+60-t)}-1\right]}{(1-\theta) \cdot r-\rho} c(v, t)^{\theta}=[A(v, t)+\bar{W}(v, t)]^{\theta}
$$

Which implies that

$$
c(v, t)=\left[\frac{(1-\theta) \cdot r-\rho}{e^{[(1-\theta) \cdot r-\rho](v+60-t)}-1}\right]^{\frac{1}{\theta}}[A(v, t)+\bar{W}(v, t)]
$$

According to equation (A59), optimal consumption is proportional to total wealth. 
We have defined the human capital $\bar{W}(v, t)$ in equations (A51a) and (A51b), for young and old, respectively. Below we will show how the asset $A(v, t)$ is defined in equations (A63) and (A65), for young and old, respectively.

Since a person enters the economy without financial wealth at $t=v$, it follows from (A59) that

$c(v, v)=\left[\frac{(1-\theta) \cdot r-\rho}{e^{60[(1-\theta) \cdot r-\rho]}-1}\right]^{\frac{1}{\theta}} \bar{W}(v, v)$

From equation (A56) we know, assuming a constant $\mathrm{r}$ :

$c(v, s)^{-\theta} e^{-\rho(s-t)}=c(v, t)^{-\theta} e^{-r(s-t)}$ hence $c(v, t)=c(v, s) e^{\frac{1}{\theta}(r-\rho)(t-s)}$

The Euler equation (A4) shows that $c(v, t)=c(v, v) e^{\frac{1}{\theta}(r-\rho)(t-v)}$ in the young period $(v \leq t \leq v+40)$, so that we obtain:

$c(v, t)=e^{\frac{1}{\theta}(r-\rho)(t-v)}\left[\frac{(1-\theta) \cdot r-\rho}{e^{60[(1-\theta) \cdot r-\rho]}-1}\right]^{\frac{1}{\theta}} \bar{W}(v, v)$

For the young generation $v \leq t \leq v+40$ ), asset accumulation follows:

$\AA(v, t)=r A(v, t)+\left[1-\tau^{g}(t)-(1-\beta) \tau^{p}(t)\right] p w(t)-c(v, t)$

Where $c(v, t)$ is defined according to equation (A61).

Solve $A(v, t)$ from

$$
A(v, t)=A(v, t) e^{-r t}+r \int_{v}^{t} A(v, t) e^{-r t} d t=r \int_{v}^{t} A(v, t) e^{-r t} d t+\int_{v}^{t}\left[1-\tau^{g}-(1-\beta) \tau^{p}\right] p w e^{-r t} d t-\int_{v}^{t} c(v, t) e^{-r t} d t
$$




$$
\begin{aligned}
& A(v, t)=-\frac{e^{r t}\left[1-\tau^{g}-(1-\beta) \tau^{p}\right] p w}{r}\left(e^{-r t}-e^{-r v}\right) \\
& -e^{r t} e^{\frac{(\rho-r) v}{\theta}}\left[\frac{(1-\theta) r-\rho}{e^{60[(1-\theta) r-\rho]}-1}\right]^{\frac{1}{\theta}}\left[e^{\frac{(1-\theta) r-\rho}{\theta} t}-e^{\frac{(1-\theta) r-\rho}{\theta} v}\right] \frac{\theta}{(1-\theta) r-\rho} \bar{W}(v, v) \\
& =\frac{e^{r(t-v)}-1}{r}\left[1-\tau^{g}(t)-(1-\beta) \tau^{p}(t)\right] p w(t)+\left[\frac{(1-\theta) r-\rho}{e^{60[(1-\theta) r-\rho]}-1}\right]^{\frac{1}{\theta}}\left[e^{r(t-v)}-e^{\frac{r-\rho}{\theta}(t-v)}\right] \frac{\theta}{(1-\theta) r-\rho} \bar{W}(v, v)
\end{aligned}
$$

Thus assets for the young are given by equation (A63).

For the old generation $(v+40<t \leq v+60)$, asset accumulation follows:

$$
\AA v, t)=r A(v, t)+\left[\eta^{g}(t)+\eta^{p}(t)\right]-c(v, t)
$$

Where $c(v, t)=e^{\frac{1}{\theta}(r-\rho)(t-v-41)} c(v, v+41)$ with

$$
c(v, v+41)=\left[\frac{(1-\theta) \cdot r-\rho}{e^{19[(1-\theta) \cdot r-\rho]}-1}\right]^{\frac{1}{\theta}}[A(v, v+41)+\bar{W}(v, v+41)]
$$

Solve $A(v, t)$ using the same method mentioned above

$$
\begin{aligned}
& A(v, t)=-\frac{e^{r t}\left(\eta^{g}(t)-\eta^{p}(t)\right)}{r}\left(e^{-r t}-e^{-r(v+41)}\right) \\
& -e^{r t} e^{\frac{(\rho-r)(v+41)}{\theta}}\left[e^{\frac{(1-\theta) r-\rho}{\theta} t}-e^{\frac{(1-\theta) r-\rho}{\theta}(v+41)}\right] \frac{\theta}{(1-\theta) r-\rho} c(v, v+41) \\
& =A(v, v+40) e^{r^{b}(t-v-40)}+\frac{e^{r(t-(v+41))}-1}{r}\left(\eta^{g}(t)+\eta^{p}(t)\right)+\left[e^{r(t-v-41)}-e^{\frac{r-\rho}{\theta}(t-v-41)}\right] \frac{\theta}{(1-\theta) r-\rho} c(v, v+41)
\end{aligned}
$$

Thus assets for the old are given by equation (A65).

Then we can define savings as follows: 


$$
\begin{array}{lr}
s(v, t)=\left[1-\tau^{g}(t)-(1-\beta) \tau^{p}(t)\right] p w(t)-c(v, t) & v \leq t \leq v+40 \\
s(v, t)=\left[\eta^{g}(t)+\eta^{p}(t)\right]-c(v, t) & v+40<t \leq v+60
\end{array}
$$

\section{Pension fund}

Population is of size $N$, which is distributed uniformly over ages indicated by $v$. The pension fund has wealth $W_{t}^{p}$ at moment $t$, it receives a premium $\tau_{v, t}^{p} p w_{v, t}$ from workers of age $v$ and pays out benefits $\eta_{v, t}^{p}$ to retirees of age $v$. The wealth is invested in equity at return $r_{t}^{e}$. Therefore, the pension fund wealth accumulates according to:

$$
W_{t}^{p}=r_{t}^{e} W_{t}^{p}+\int_{25}^{65} N \tau_{v, t}^{p} p w_{v, t} d v-\int_{65}^{85} N \eta_{v, t}^{p} d v
$$

We assume the premium rate $\tau^{p}$ and wage $w$ are the same for all ages of workers, that is $\tau_{v, t}^{p}=\tau_{t}^{p}$ and $w_{v, t}=w_{t}$. Similarly the benefit $\eta^{p}$ is the same for all retirees, i.e. $\eta_{v, t}^{p}=\eta_{t}^{p}$. Then we can simplify equation (A68) to:

$W_{t}^{p}=r_{t}^{e} W_{t}^{p}+40 N \tau_{t}^{p} p w_{t}-20 N \eta_{t}^{p}$

By paying a pension premium a young individual of age $v$ at moment $t$ obtains a pension right $l_{v, t}^{p}$ The pension right is essentially an annuity which grows over time at rate $r^{b}$. For, individuals are only willing to participate in the pension fund when this guarantees them a return on assets which they could at least yield themselves. As a consequence, the young individual's pension wealth $L_{v, t}^{p, y}$ accumulates as follows:

$$
E_{v, t}^{\alpha, y}=r_{t}^{b} L_{v, t}^{p, y}+l_{v, t}^{p} \quad v \leq t \leq v+40
$$


For simplicity we assume the pension right to be identical for all age groups and constant over time - hence $l_{v, t}^{p}=l_{t}^{p}$. From equation (A70) we can solve $L_{v, t}^{p, y}$, which yields:

$$
L_{v, t}^{p, y}=\frac{l^{p}}{r^{b}}\left[e^{r^{b}(t-v)}-1\right] \quad v \leq t \leq v+40
$$

With $L_{v, v}^{p, y}=0$ as starting value and which ends at $L_{v, v+40}^{p, y}=\frac{l^{p}}{r^{b}}\left(e^{40 r^{b}}-1\right)$.

For the old generation the individuals' pension wealth is the accumulation of pension rights minus the pension benefits that have been paid out. Therefore

$$
\mathcal{L}_{v, t}^{\&, o}=r_{t}^{b} L_{v, t}^{p, o}-\eta_{v, t}^{p} \quad v+40<t \leq v+60
$$

with $L_{v, v+40}^{p, y}=\frac{l^{p}}{r^{b}}\left(e^{40 r^{b}}-1\right)$ as starting value and which ends at $L_{v, v+60}^{p, o}=0$.

Similarly from equation (A72), we can solve $L_{v, t}^{p, o}$, leading to:

$$
L_{v, t}^{p, o}=L_{v, v+40}^{p, y} e^{r^{b}(t-v-40)}+\frac{\eta^{p}}{r^{b}}\left[1-e^{r^{b}(t-v-40)}\right] v+40<t \leq v+60
$$

When benefits are constant over time, i.e. $\eta_{v, t}^{p}=\eta^{p}$. The starting value of $L_{v, t}^{p, o}$ is $L_{v, v+40}^{p, y}$ and the end value should be $L_{v, v+60}^{p, o}=0$. The latter implies:

$l^{p}=\frac{\eta^{p}}{e^{60 r^{b}}-e^{20 r^{b}}}\left(e^{20 r^{b}}-1\right)$

Then the sum of the individual's pension wealth at moment $\mathrm{t}\left(L_{v, t}^{p}\right)$ is the liability of the pension fund $P_{t}^{p}$. 
$P_{t}^{p}=N \int_{t-60}^{t} L_{v, t}^{p} d v$

According to equation (A71), the liability for the young generation is equal to the accumulated pension rights $\left(l^{p}\right)$ up to moment t. And according to equation (A73), the liability for the old generation is equal to the accumulated pension rights in the young period minus the pension benefits $\left(\eta^{p}\right)$ that have been paid.

Therefore, the pension liability of the pension fund is:

$$
\begin{aligned}
& P_{t}^{p}=N \int_{t-60}^{t} L_{v, t}^{p} d v=N \int_{t-40}^{t} L_{v, t}^{p, y} d v+N \int_{t-60}^{t-40} L_{v, t}^{p, o} d v \\
& =N \int_{t-40}^{t} \frac{l^{p}}{r^{b}}\left[e^{r^{b}(t-v)}-1\right] d v+N \int_{t-60}^{t-40}\left\{\frac{l^{p}}{r^{b}}\left(e^{40 r^{b}}-1\right) e^{r^{b}(t-v-40)}+\frac{\eta^{p}}{r^{b}}\left[1-e^{r^{b}(t-v-40)}\right]\right\} d v \\
& =\frac{N l^{p}}{r^{2 b}}\left(e^{40 r^{b}}-1\right) e^{20 r^{b}}-\frac{40 N l^{p}}{r^{b}}+\frac{20 N \eta^{p}}{r^{b}}+\frac{N \eta^{p}}{r^{2 b}}\left(1-e^{20 r^{b}}\right)
\end{aligned}
$$

Substituting equation (A74) into equation (A76) yields:

$$
P_{t}^{p}=\frac{20 N \eta^{p}}{r^{b}}-\frac{40 N \eta^{p}}{r^{b}\left(e^{60 r^{b}}-e^{20 r^{b}}\right)}\left(e^{20 r^{b}}-1\right)
$$

According to equations (A70) and (A72), the accumulated individual's pension wealth can be aggregated as:

$$
\begin{aligned}
& \&_{t}^{\&}=N \int_{t-60}^{t} \&_{v, t}^{\&} d v=N \int_{t-40}^{t} \sum_{v, t}^{\&, y} d v+N \int_{t-60}^{t-40} \sum_{v, t}^{\alpha, o} d v \\
& =N \int_{t-40}^{t}\left(r^{b} L_{v, t}^{p, y}+l_{v, t}^{p}\right] d v+N \int_{t-60}^{t-40}\left(r^{b} L_{v, t}^{p, o}-\eta_{v, t}^{p}\right) d v=r^{b} \int_{t-60}^{t} L_{v, t}^{p} d v+N \int_{t-40}^{t} l_{v, t}^{p} d v-N \int_{t-60}^{t-40} \eta_{v, t}^{p} d v
\end{aligned}
$$


We assume the benefits $\eta^{p}$ is the same for all retirees and the pension rights $l^{p}$ is the same for all workers. Then we can simplify equation (A78) to:

$$
\mathcal{E}_{t}=N r^{b} \int_{t-60}^{t} L_{v, t}^{p} d v+40 N l_{t}^{p}-20 N \eta_{t}^{p}
$$

The accumulated liability of the pension fund is equal to the aggregated accumulated individual's pension wealth.

$$
\mathcal{E}_{t}^{p}=\mathcal{L}_{t}^{\alpha}=N r^{b} \int_{t-60}^{t} L_{v, t}^{p} d v+40 N l_{t}^{p}-20 N \eta_{t}^{p}
$$

With $P_{t}^{p}=N \int_{t-60}^{t} L_{v, t}^{p} d v$, equation (A80) can be written as:

$$
\mathcal{L}_{t}^{p}=r^{b} P_{t}^{p}+40 N l_{t}^{p}-20 N \eta_{t}^{p}
$$

The accumulation of the wealth in the pension fund equals to the accumulation of the liability in the pension fund, therefore does hold

$$
W_{t}^{p}=p_{t}^{p e}
$$

From equations (A69) and (A81) we then find

$$
\begin{aligned}
& r_{t}^{e} W_{t}^{p}+40 N \tau_{t}^{p} p w_{t}-20 N \eta_{t}^{p}=r^{b} P_{t}^{p}+40 N l_{t}^{p}-20 N \eta_{t}^{p} \\
& \tau_{t}^{p}=\frac{1}{40 N p w_{t}}\left(r_{t}^{b} P_{t}^{p}+40 N l_{t}^{p}-r_{t}^{e} W_{t}^{p}\right)
\end{aligned}
$$

In the steady state, the pension fund wealth $\left(W^{p}\right)$ equals to the pension fund liability $\left(P^{p}\right)$. Equation (A82) can be written as: 


$$
\tau^{p}=\frac{1}{40 N p w}\left[40 N l^{p}-\left(r^{e}-r^{b}\right) P^{p}\right]
$$

Substituting equations (A74) and (A77) in equation (A83), we get:

$$
\begin{aligned}
& \tau^{p}=\frac{l^{p}}{p w}-\frac{1}{40 N p w}\left(r^{e}-r^{b}\right) P^{p}=\frac{e^{20 r^{b}}-1}{e^{60 r^{b}}-e^{20 r^{b}}} \xi^{p}-\left(\frac{r^{e}}{r^{b}}-1\right) \xi^{p}\left(\frac{1}{2}-\frac{e^{20 r^{b}}-1}{e^{60 r^{b}}-e^{20 r^{b}}}\right) \\
& =\frac{r^{e}}{r^{b}} \frac{e^{20 r^{b}}-1}{e^{60 r^{b}}-e^{20 r^{b}}} \xi^{p}-\frac{1}{2}\left(\frac{r^{e}}{r^{b}}-1\right) \xi^{p}
\end{aligned}
$$

With $\eta^{p}=\xi^{p} p w$

When the accumulated wealth is not equal to the accumulated liability because of an unexpected shock, the pension fund will adjust the premium according to:

$$
\tau_{t}^{p}=\frac{1}{40 N p w_{t}}\left[\left(r_{t}^{b} P_{t}^{p}+40 N l_{t}^{p}-r_{t}^{e} W_{t}^{p}\right)-\varphi\left(W_{t}^{p}-P_{t}^{p}\right)\right.
$$

\section{Simulation process:}

With the equations derived in the previous two sections for the consumers and pension fund and the equations in the paper for the firm and public sector, we can simulate the model in the steady state and in the situation with shocks.

In the steady state, with equation (A84), (5) and (16), pension premium, wage and PAYG tax rate can be calculated. Then according to equation (A59), consumption of young can be calculated by aggregating the consumptions of 45 young generations. And consumption of old can also be calculated by aggregating the consumptions of 15 old generations. Finally, the saving can be derived from equation (A66) and (A67), for young and old, respectively. 
If the shock affects the pension fund, equation (A85) can be used to derive how the pension premium is affected dynamically. With the dynamics of the pension premium known, using equation $\mathrm{A}(59)$ the dynamics of consumption of young and consumption of old can be derived. And the dynamics of saving can be derived according to equation (A66) and (A67).

When the shock affects the PAYG pillar, equation (5) can be used to derive how the PAYG tax rate is affected dynamically. According to the dynamics of the PAYG tax rate, the dynamics of consumption of young and consumption of old can be concluded with equation (A59). Then the dynamics of saving can be concluded with equations (A66) and (A67). 